\title{
HISTOPATHOLOGICAL STUDIES ON SOME ORGANS OF OREOCHROMIS NILOTICUS, TILAPLA ZILLII AND SYNODONTIS SCHALL FROM EL-SALAM CANAL, EGYPT
}

\author{
Fatma Abd El-Moghney S. Mohamed
}

National Institute of Oceanography and Fisheries, Inland Waters and Aquaculture Branch, Al-Qanater Al-Khairya Fish Research Station, Cairo, Egypt.

Key words: pollution, histopathology, gills, liver, kidneys, gonads, Oreochromis niloticus, Tilapia zillii, Synodontis schall, El-Salam Canal.

\section{ABSTRACT}

$I^{n}$ $\mathrm{n}$ the present study, the histological structures of the gills, liver, kidneys and gonads of Oreochromis niloticus, Tilapia zillii and Synodontis schall from El-Salam canal were studied for a period extending from spring 2000 to winter 2001 (4 successive seasons). Several histopathological changes were observed in the gills, liver, kidneys and gonads of the studied fish during the four seasons.

In the gills, proliferative changes in the epithelium of gill filaments and secondary lamellae, degenerative and necrotic changes in gill filaments, separation of the epithelium of the secondary lamellae from the lamellar supporting cells in gill filaments, intravascular haemolysis and dilation in the blood vessels of gill filaments, haemorrhage between gill filaments, edema in secondary lamellae and mucus accumulation between gill filaments were seen.

In the liver, vacuolar degeneration, focal areas of coagulative necrosis, focal areas of necrosis, destruction of hepatoportal biood vessels and haemorrhage between the hepatocytes were observed. Besides, intravascular haemolysis and dilation were seen in hepatic and hepatoportal blood vessels. Also, dilation and congestion were noticed in blood sinusoids.

In the kidneys, the histopathological changes included vacuolar degeneration in the epithelium of renal tubules, focal areas of necrosis between the renal tubules, depletion in the haemopoietic areas, haemolysis between the renal tubules and edema in Bowman's capsules. Moreover, intravascular haemolysis in renal blood vessels and over population of glomeruli were observed. 
In the testis, degenerative and necrotic changes in the cellular elements of seminiferous tubules, with inhibition of spermatogenesis (some seminiferous tubules appeared lucent or with a lesser number of sperms, indicating lack of active spermatogenesis), focal areas of necrosis and fibrous capsules around some seminiferous tubules were observed. Besides, malformation and distortion of the architecture of some seminiferous tubules were seen.

In the ovary, degenerative and necrotic changes (atresia) in the oocytes, proliferative changes in the granulosa of the oocytes, resulting sometimes in adhesion of the cellular coat of the oocytes, haemorrhage between the oocytes and intravascular haemolysis in some ovarian blood vessels were seen. Moreover, focal areas of necrosis, aggregations of haemosiderin between the oocytes and separation of the follicular layers from the oocytes were observed.

These histopathological alterations showed marked seasonal variations, where, they were more severe during winter. The results indicated that Oreochromis niloticus is more sensitive to pollution than Tilapia zillii and Synodontis schall.

\section{INTRODUCTION}

The aquatic environment is subjected to different types of pollutants which enter water bodies with industrial, domestic and agricultural waste waters and affect severely the aquatic organisms. The problems of environmental pollution and its deleterious effects on aquatic organisms received focused interest during the last decades.

El-Salam canal is one of the most important projects in Egypt, since it transports the Nile water to Sinai. The canal runs to the south of Lake Manzalah towards the northern area of Sinai. It is intended to supply enough irrigation water for about 450,000 feddans as a potential area for agriculture development in northern Sinai. The canal is carrying the Nile water from Damietta branch upstream of Faraskour Barrage (a total amount of 2110 million $\mathrm{m}^{3} / \mathrm{year}$ ) in addition to drainage water from El-Serw and Hadous drains (2050 million $\mathrm{m}^{3} /$ year drainage water) (Sabae and Abdel-Satar, 2001).

Previous studies reported that El-Salam canal is contaminated with heavy metals, bacteria indicative of sewage pollution and ammonia (Abdel - Baky, 2001, Bahnasawy, 2001, Rabeh, 2001 and Sabae and Abdel-Satar, 2001). Therefore, the increasing amount of agricultural, domestic and industrial drainage water which 


\section{HISTOPATHOLOGICAL STUDIES ON SOME ORGANS 101 OF O. NILOTICUS, T. ZILLII AND S. SCHALL}

discharged into El-Salam canal may exert considerable changes in the histological structures of the different organs of the fish.

Several histopathological changes have been reported in the gills, liver, kidneys and gonads of fish in response to agricultural, sewage and industrial poilutants. Histopathological changes in the gills were observed in Fundulus heteroclitus exposed to cadmium (Gardner and Yevich, 1970), in channel catfish, Ictalurus punctatus, experimentally and naturally infected with channel catfish virus disease (Major et al., 1975), in Thymallus arcticus infected with ectoparasite monogenetic trematode, Tetraonchus rauschi (Wobeser et al., 1976), in blue gill, Lepomis macrochirus, exposed to monochloramine (Bass et al, 1977), in mummichogs, Fundulus heteroclitus, exposed to naphthalene (DiMichele and Taylor, 1978), in steelhead trout, Salmo gairdneri, exposed to nitrite (Wedemeyer and Yasutake, 1978), in immature rainbow trout exposed to crude oil (Enghelhardt et al, 1981), in Ictalurus punctatus exposed to a combination of ammonia and low levels of monochloranine (Mitchell and Cech, 1983), in Sarotherodon mossambicus exposed to $\mathrm{HgCl}_{2}$ (Naidu et al, 1983), in fathead minnows, Pimephales promleas, experimentally exposed to acidified Canadian Lakes (Leino et al., 1987), in Tilapia nilotica exposed to lead acetate, mercuric chloride and cadmium chioride (Balah et al., 1993), in carp, Cyprinus carpio, exposed to 20 and $50 \%$ sewage (Kakuta and Murachi, 1997), in Tilapia zillii exposed to phenol (Marie et al., 1997 a\&b), in Salmo trutta exposed to iron sulphate (Dalzell and Macfarlane, 1999), in Oreochromis niloticus exposed to pesticides, reldan, roundup and lannate (Mohamed, 1999) and in Tilapia zillii exposed to lindane (Mourad et al., 1999).

Histopathological changes in the liver of fish as a result of exposure to toxicants have been studied by several authors (Couch, 1975, Major et al., 1975, Li et al., 1978, Sastry and Malik, 1979, Dixon and Leduc, 1981 and Desai et al., 1984). Several histopathological changes in the liver were also observed in ruffe, gymnocephalus cernua, collected from Elbe Estuary contaminated by domestic, industrial and agricultural pollutants (Heidemarie and Peters, 1985), in Atlantic tomcod, Microgadus tomcod, collected from contaminated Hudson River (Cormier, 1986), in Tilapia nilotica exposed to diazinon (Issa and Gabr, 1989), in Tilapia nilotica exposed to fluorine and sulphur emitting from factory of fertilizer (Aly et al., 1992), in Clarias lazera exposed to bayluscide (Hamza et al., 1996), in Tilapia zillii exposed to lindane (Mourad et al., 1999) 
and in Oreochromis niloticus and Tilapia zillii collected from the southern region of Lake Manzalah contaminated with domestic, industrial and agricultural pollutants (Mohamed, 2001 b).

The histopathological alterations in the kidneys of fish induced by exposure to different toxicants have been reported by several authors (Gardner and Yevich, 1970, Wolf et al., 1972, Major et al., 1975, Li et al., 1978, Kumar and Srivastava, 1980 and Sastry and Sharma, 1981). Histopathological changes in the kidneys were also observed in plaice, Pleuronectes platessa, exposed to crude oil (Haensly et al., 1982), in European eels, Anguilla anguilla, infected with the parasite Myxidium giardi Cépède (Ventura and Paperna, 1984), in Tilapia nilotica exposed to pyrethroid insecticide (neopybuthrin) (Gabr, 1990), in Tilapia nilotica exposed to fluorine and sulphur emitting from factory of fertilizer (Aly et al., 1992), in Oreochromis niloticus infected by Streptococcus sp. (Chang and Plumb, 1996), in carp (Cyprinus carpio) exposed to 20 and 50\% sewage (Kakuta and Murachi, 1997), in Tilapia zillii exposed to phenol (Marie et al., 1997b) and in Oreochromis niloticus exposed to pesticides, reldan, roundup and lannate (Mohamed, 1999).

Histopathological changes were seen in the testis of Salmo gairdneri exposed to cyanide (HCN) (Sylvia et al., 1979), in the ovary of rainbow trout exposed to cyanide (HCN) (Lesniak and Ruby, 1982), in the ovary of Puntius conchonius exposed to zinc (Kumar and Pant, 1984), in the ovary of Oreochromis mossambicus exposed to malathion (Shukla et al., 1984), in the gonads of winter flounder and cod infected with the hemoflagellate Trypanosoma murmanensis and then exposed to Venezuelan crude oil (Khan, 1987), in the gonads of Monopterus albus exposed to cadmium (Singh, 1989), in the testis of catfish, Clarias batrachus L., exposed to mercuric chloride, methyl mercuric chloride and emisan 6 (an organic mercurial fungicide) (Kirubagaran and Joy, 1992), in the ovary of Oreochromis niloticus infected by Streptococcus sp. (Chang and Plumb, 1996) and in the gonads of Tilapia zillii exposed to phenol (Mohamed, 2001a).

The present study aims to illustrate the harmfull effects of pollution of El-Salam canal on the histological features of four organs (gills, liver, kidneys and gonads) of the commercially important fish Oreochromis niloticus, Tilapia zillii and Synodontis schall. 


\section{HISTOPATHOLOGICAL STUDIES ON SOME ORGANS 103 OF O. NILOTICUS, T. ZILLII AND S. SCHALL}

\section{MATERIAL AND METHODS}

Samples of Oreochromis niloticus $(150-200 \mathrm{~g})$, Tilapia zillii $(150-200 \mathrm{~g})$ and Synodontis schall $(100-150 \mathrm{~g})$ were collected seasonally during a period extending from spring, 2000 to winter, 2001 from El-Salam canal. During the same period, control samples of the studied fish were collected from the River Nile, at Al-Kanater Al-Khairya station.

Fish were dissected and pieces of gills, liver, kidneys and gonads were immediately isolated and fixed in Bouin's fluid for 24$48 \mathrm{hrs}$. After fixation, the tissues were washed in $70 \%$ ethyl alcohol to get rid of excess fixative and then dehydrated through ascending grades of ethyl alcohol $(70 \% 1 \mathrm{hr}, 80 \% 1 \mathrm{hr}, 90 \% \mathrm{l} \mathrm{hr}$ and $100 \%$ changed twice during $1 \mathrm{hr}$ ). The specimens were cleared in xylene for 15-20 min and infiltrated with and embedded in paraffin wax. The paraffin wax block was sectioned at the thickness $4-6 \mu \mathrm{m}$. Sections were mounted on clear glass slides and were stained with Harris' haematoxylin and eosin.

\section{Gills:}

\section{RESULTS}

The histological investigations indicated that the gills of control Oreochromis niloticus, Tilapia zillii and Synodontis schall-collected from the River Nile, at Al-Kanater Al-Khairya stationhave a normal architecture (Fig. 1A).

Several histopathological changes were seen in the gills of the studied fish - collected from El-Salam canal - during the four seasons (spring, summer, autumn and winter).

Spring:

During spring season, the gills of Oreochromis niloticus showed proliferative changes in the epithelium of some gill filaments and secondary lamellae, resulting sometimes in obliteration of the space between the secondary lamellae (Fig. 1B), degenerative and necrotic changes in some gill filaments (Fig. 1F) and separation of the epithelium of the secondary lamellae from the lamellar supporting cells in some gill filaments (Fig. 3A\&C). Severe dilation and congestion in the blood vessels were seen in some gill filaments (Fig. 2D). Severe haemorrhage was also observed between the gill filaments (Fig. 3A\&C).

The gills of Tilapia zillii showed slight degenerative and necrotic changes in some gill filaments and severe dilation and congestion in the blood vessels of some gill filaments (Fig. 2D). 
Moreover, proliferative changes were seen only in the epithelium at the base of the secondary lamellae. However, the gills of Synodontis schall showed slight degenerative and necrotic changes in some gill filaments, slight haemorrhage between the gill filaments and dilation in the blood vessels of some gill filaments.

\section{Summer and autumn:}

During summer and autumn seasons, the gills of $O$. niloticus showed the same histopathological alterations observed in the gills of $O$. niloticus during spring season. Besides, accumulation of mucus was noticed between the gill filaments in some fish.

In the gills of $T$. zillii, proliferative changes were observed in the epithelium of the secondary lamellae resulting in nodular proliferation in some gill filaments (Fig. 2E). In other gill filaments, the proliferative changes were noticed only in the epithelium at the base of the secondary lamellae (Fig. 2E). Moreover, degenerative and necrotic changes were observed in some gill filaments (Fig. 1F). Also, slight haemorrhage was seen between the gill filaments during summer season.

The gills of $S$. schall showed the same histopathological changes observed in the gills of $S$. schall during spring season. Besides, slight proliferative changes in the epithelium of some gill filaments and secondary lamellae and separation of the epithelium of the secondary lamellae from the lamellar supporting cells in some gill filaments (Fig. 3B) were noticed.

\section{Winter :}

During winter season, the histopathological alterations in the gills of the three studied fish appeared more severe. The histopathological changes in the gills of $O$. niloticus included separation of the epithelium of the secondary lamellae from the lamellar supporting cells in most gill filaments and severe proliferative changes in the epithelium of some gill filaments and secondary lamellae, resulting in obliteration of the space between the secondary lamellae (Fig. 1D\&E). Also, excessive mucus accumulation between the gill filaments (Fig.2A) and severe degenerative and necrotic changes in the gill filaments - the secondary lamellae appeared destructed and necrotized tissues aggregated in the mucus between the gill filaments - (Fig. 2A) were seen. Moreover, intravascular haemolysis and dilation were observed in the blood vessels of some gill filaments (Fig. 2F). Edema was also seen in the secondary lamellae (Fig. 2G). 
However, in the gills of $T$. zillij and $S$. schall, severe degenerative and necrotic changes in the gill filaments (Fig. 2B) and separation of the epithelium of the secondary lamellae from the lamellar supporting cells in some gill filaments (Fig. 3D) were noticed. Besides, proliferative changes were observed in the epithelium of the secondary lamellae resulting sometimes in obliteration of the space between the secondary lamellae (Fig. IC). Severe dilation and congestion in the blood vessels of some gill filaments (Fig. 2C) and excessive mucus accumulation between the gill filaments (Fig. 2B) were seen.

\section{II- Liver:}

The histological structures of the liver of control $O$. niloticus, T. zillii and $S$. schall are shown in fig. 3E. No abnormal histological features were observed.

Several histopathological alterations were observed in the liver of the studied fish - collected from El-Salam canal - during the four seasons.

\section{Spring :}

During spring season, the liver of $O$. niloticus showed focal areas of coagulative necrosis (Fig. 4A), small multiple vacuoles in the hepatocytes and sometimes this vacuolar degeneration appeared pronounced and the hepatocytes appeared empty (Fig. 6B) and focal areas of necrosis (Fig. 5B). Also, destruction of some hepatoportal blood vessels was seen (Fig. 5A). Besides, haemorrhage and aggregations of inflammatory cells were observed between the hepatocytes (Fig. 5D). Moreover, in some cases, dilation was noticed in the central veins (Fig. 4F).

The hepatocytes of $T$. zillii showed slight vacuolar degeneration and dissociation. Also, small focal areas of coagulative necrosis (Fig. 4A) were observed. In addition, destruction of some hepatoportal blood vessels was observed. (Fig. 5A). Also, slight haemorrhage was noticed between the hepatocytes. Dilation and congestion were also seen in some blood sinusoids (Fig. 5F). Thrombosis formation was observed in some hepatoportal blood vessels (Fig. 4B).

In $S$. schall, the liver showed vacuolar degeneration in the hepatocytes (Fig. 6C), small focal areas of necrosis, haemorrhage between the hepatocytes and destruction of some blood vessels. Moreover, haemolysis was seen in some blood sinusoids (Fig. 6A). 


\section{Summer and autumn:}

During summer and autumn seasons, the liver of $O$. niloticus showed focal areas of vacuolar degeneration in the hepatocytes (Fig. 6D), focal areas of coagulative necrosis, focal areas of necrosis (Fig. 5B) and haemorrhage between the hepatocytes. Besides, during summer season, thrombosis formation was seen in some hepatic (Fig. 4C) and hepatoportal (Fig. 4B) blood vessels.

The liver of $T$. zilliii showed focal areas of vacuolar degeneration in the hepatocytes, focal areas of necrosis, destruction of some hepatoportal blood vessels and haemorrhage between the hepatocytes. Moreover, during summer, severe haemolysis and dilation were observed in some hepatoportal blood vessels of some fish (Fig. 4D).

In $S$. schall, the liver showed the same histopathological alterations observed in the liver of $S$. schall during spring season, however, the vacuolar degeneration was more pronounced.

Winter:

During winter, the histopathological changes in the liver of the three studied fish appeared more severe. In the liver of $O$. niloticus, extensive vacuolar degeneration in the hepatocytes (Fig.6E\&F), focal areas of coagulative necrosis, multiple focal areas of necrosis (Fig. 5C) and severe haemorrhage between the hepatocytes (Fig. 5E) were seen. Moreover, severe intravascular haemolysis and dilation were observed in some hepatic (Fig. 4E) and hepatoportal (Fig. 4D) blood vessels.

The liver of $T$. zillii and $S$. schall showed the same histopathological changes observed in the liver of $O$. niloticus, however, the pathological changes appeared more pronounced in the liver of $O$. niloticus.

\section{Kidney:}

The histological investigations indicated that the kidneys of control $O$. niloticus, T. zillii and S. schall-collected from the River Nile, at Al-Kanater Al-Khairya station-have a normal architecture (Fig. 6G).

Several histopathological alterations were observed in the kidney of the studied fish-collected from El-Salam canal-during the four seasons.

\section{Spring:}

During spring season, the kidney of $O$. niloticus showed vacuolar degeneration in the epithelium of some renal tubules (Fig. 
8C) and focal areas of haemolysis and aggregation of inflammatory cells between the renal tubules (Fig. TE).

In the kidney of $T$. zillii, slight vacuolar degeneration in the epithelium of some renal tubules, depletion in the haemopoietic areas (Fig. 7H) and slight haemolysis between the renal tubules were seen. Moreover, dilation of the capillary tubes of some renal tubules was noticed (Fig. 7C).

The histopathological alterations in the kidney of $S$. schall included slight vacuolar degeneration in the epithelium of some renal tubules, aggregation of inflammatory cells (Fig. 6H) and slight haemolysis between the renal tubules and congestion of the capillary tubes of some renal tubules (Fig. 7D).

Summer and autumn:

During summer and autumn seasons, the kidney of 0 . niloticus showed the same histopathological changes observed in the kidney of $O$. niloticus during spring, however, the vacuolar degeneration in the epithelium of the renal tubules was more pronounced during summer and autumn seasons. Small focal areas of necrosis were also seen between the renal tubules (Fig. 8D). Moreover, during autumn, edema was observed in some Bowman's capsules (Fig. 7A).

In $T$. zillii and $S$. schall, the kidney showed the same histopathological changes observed in the kidney of these fish during spring.

Winter:

During winter season, as in the gills and liver, the histopathological alterations in the kidney of the three studied fish appeared more severe. In the kidney of $O$. niloticus, the pathological changes included extensive vacuolar degeneration in the epithelium of renal tubules (Fig. 7B), focal areas of necrosis (Fig. 8B), severe haemolysis between the renal tubules (Fig. 7F) and in some renal blood vessels (Fig. 8A), depletion in the haemopoietic areas (Fig. $7 \mathrm{H}$ ), edema in most Bowman's capsules and dilation of the capillary tubes of some renal tubules (Fig. 7B).

The kidney of $T$. zillii and $S$. schall showed vacuolar degeneration in the epithelium of renal tubules and focal areas of necrosis (Fig. 8B). Moreover, intravascular haemolysis in some renal blood vessels (Fig. 8A) and severe haemolysis between the renal tubules (Fig. 7G) were seen. Besides, depletion in the haemopoietic areas (Fig. $7 \mathrm{H}$ ) and over population of glomeruli (Fig. 8A) were observed in the kidney of T. zillii. 
IV. Testes :

The histological structures of the testes of control $O$. nilolicus, T. zillii and S. schall are shown in fig. 8E, no abnormal histological features were observed.

Several histopathological alterations were observed in the testes of the studied fish - collected from El-Salam canal - during the four seasons.

\section{Spring:}

During spring season, the testes of $O$. niloticus showed degenerative and necrotic changes in the cellular elements of some seminiferous tubules (Fig. 9D). Some seminiferous tubules revealed a lesser number of sperms or appeared lucent (without sperms) indicating lack of active spermatogenesis (Fig. 10A).

On the other hand, the testes of $T$. zillii and $S$. schall showed slight degenerative and necrotic changes in the cellular elements of some seminiferous tubules.

\section{Summer and autumn:}

During summer and autumn seasons, the testes of $O$. niloticus showed the same pathological changes observed in the testes of $O$. niloricus during spring. Besides, small focal areas of necrosis were seen in the testes (Fig. 9B). Fibrous capsule was observed around some seminiferous tubules (Fig. 10D).

In the testes of $T$. zillii and $S$. schall, degenerative and necrotic changes in the cellular elements of some seminiferous tubules (Fig. 9E) and small focal areas of necrosis (Fig. 9E) were seen. Moreover, some seminiferous tubules revealed a lesser number of sperms or appeared lucent (Fig. 10B). Malformations and distortion of the architecture of some seminiferous tubules were observed in the testes of $T$. zillii (Fig. 9E). In some cases, sperms were observed between the seminiferous tubules in the testes of $T$. zillii during summer (Fig. 9E).

\section{Winter :}

During winter, the histopathological alterations in the testes of the studied fish appeared more severe. In the testes of $O$. niloticus, the histopathological changes included multiple focal areas of necrosis, degenerative and necrotic changes in the cellular elements of most seminiferous tubules (Fig. 9C) and focal areas of coagulative necrosis (Fig. 9A). Some seminiferous tubules revealed a lesser number of sperms or appeared lucent. Fibrous capsule was seen around some seminiferous tubules (Fig. 10C). 
The testes of $T$. zillii and $S$. schall showed the same histopathological changes observed in the testes of both fish during summer and autumn. However, the pathological alterations appeared more pronounced during winter.

\section{Ovaries:}

The ovaries of control O. niloticus. T. zillii and S. schall are shown in fig. 10E, no abnormal histological features were observed.

Several histopathological changes were seen in the ovaries of the studied fish - collected from El-Salam canal - during the four seasons.

Spring :

During spring season, the ovaries of $O$. niloticus and T. zillii showed degenerative changes (atresia) in some oocytes.(Fig. 12B) and proliferative changes in the granulosa of some oocytes, resulting sometimes in adhesion of the cellular coat of the oocytes (Fig. 11D). Besides, some oocytes collapsed and became abnormally irregular in shape (Fig. 11A). Moreover, haemorrhage was seen between the oocytes (Fig. 11B). In addition, separation of the follicular layers from the oocytes was observed in the ovaries of O. niloticus (Fig. 10F).

On the other hand, the ovaries of $S$. schall showed degenerative changes in some oocytes (Fig. 12B) and slight haemorrhage between the oocytes. Also, some oocytes collapsed and became abnormally irregular in shape (Fig. 11A).

\section{Summer and autumn:}

During summer and autumn seasons, the ovaries of $O$. niloticus and $T$. zillii showed the same histopathological changes observed in the ovaries of both fish during spring season.

In the ovaries of $S$. schall, degenerative changes in some oocytes, separation of the follicular layers from the oocytes (Fig. 10G) and haemorrhage between the oocytes (Fig. 11B) were observed.

\section{Winter:}

During winter season, the histopathological alterations in the ovaries of the studied fish appeared more severe. In the ovaries of $O$. niloticus, the histopathological changes included degenerative and necrotic changes in the oocytes (Fig. 12A), proliferative changes in the granulosa of most oocytes, resulting sometimes in adhesion of the cellular coat of the oocytes (Fig. IIE), separation of the follicular layers from the oocytes and severe haemorrhage between the oocytes. Besides, focal aggregations of haemosiderin were observed between 
the oocytes (Fig. 11C). Moreover, thrombosis formation was seen in some ovarian blood vessels (Fig. 12C).

The ovaries of $T$. zillii and $S$. schall showed the same histopathological changes observed in the ovaries of both fish during summer and autumn; however, the pathological changes appeared more severe during winter. Moreover, thickening of the ovarian wall was observed in the ovaries of T. zillii (Fig. 10H).

\section{DISCUSSION}

The results of the present study revealed that fish collected from El-Salam canal manifested histopathological changes in the gills, liver, kidneys and gonads. The histopathological alterations observed in the gill tissues of the studied fish throughout the study period included proliferative changes in the epithelium of gill filaments and secondary lamellae, degenerative and necrotic changes in gill filaments and separation of the epithelium of the secondary gill lamellae from the lamellar supporting cells. Also, intravascular haemolysis and dilation in the blood vessels of gill filaments, haemorrhage between gill filaments, edema in secondary lamellae and mucus accumulation between gill filaments were seen.

The pathological changes may be a reaction to toxicants intake or an adaptive response to prevent the entry of the pollutants through the gill surface.

The observed dilation of the lamellar blood vessels and the presence of edematous fluid at the base of the secondary lamellae may be due to increased permeability induced by the prolonged exposure to the pollutants. This edematous fluid separated the respiratory epithelium from the underlying tissue and led to its desquamation as well as necrosis (Balah et al., 1993).

Since gills are the respiratery and osmoregulatory organ of the fish, the cellular damage observed in the gills in terms of epithelial hyperplasia, necrosis and separation of the epithelial layer from supportive tissues might impair the respiratory function of the gills by reducing respiratory surface area, and this badly affects the physiology and may lead to the death of fish.

The present study showed several histopathological changes in the liver of the studied fish. The alterations included vacuolar degeneration, focal areas of coagulative necrosis, focal areas of necrosis, destruction of hepatoportal blood vessels and haemorrhage between the hepatocytes. Also, intravascular haemolysis and dilation 


\section{HISTOPATHOLOGICAL STUDIES ON SOME ORGANS \\ OF O. NILOTICUS, T. ZILLII AND S. SCHALL}

of the hepatic and hepatoportal blood vessels and congestion and dilation in blood sinusoids were seen.

The observed fatty degeneration in the liver of the studied fish may be due to an inability of the liver cells to synthesize proteins that are normally conjugated with triglycerides in the hepatic cells as a response to the pollutants (Kadry and Abdel Mageid, 1995 and Mohamed, 2001b), a decrease in the rate of utilization of energy reserve or an enhance in the synthesis of fats in the liver (Desai et al., 1984 and Mohamed, 2001b).

The cellular degeneration observed in the liver of the studied fish may be due to the vascular dilation and intravascular haemolysis observed in the blood vessels with subsequent stasis of blood (Mohamed, 2001b).

The necrosis observed in the liver of the fish may be attributed to the destruction of the hepatoportal blood vessels which causes invasive infiltration of leucocytes and detrimental focal necrosis resulting in the complete dissolution of the hepatocytes (Ram and Singh, 1988), to a direct effect of the toxicants on the cell or to an accumulation of acetylcholine in the tissues (Desai et al., 1984).

The results of the present work revealed that fish collected from El-Salam canal have shown histopathological changes in the kidney; these included vacuolar degeneration in the epithelium of renal tubules, focal areas of necrosis between the renal tubules, depletion in the haemopoietic areas, haemolysis between the renal tubules and edema in Bowman's capsules. Besides, intravascular haemolysis in renal blood vessels and over population of glomeruli were seen.

Yokote (1982) reported that the necrosis of renal tubules affects the metabolic activities and promotes metabolic abnormalities in fish.

The present study showed several histopathological alterations in the gonads of the studied fish. In the testes, degenerative and necrotic changes in the cellular elements of seminiferous tubules, development of focal areas of necrosis, focal areas of coagulative necrosis, formation of fibrous capsules around some seminiferous tubules and malformation and distortion of the architecture of some seminiferous tubules were seen. In the ovaries, development of degenerative and necrotic changes in the oocytes, focal areas of necrosis, proliferative changes in the granulosa of the oocytes resulting sometimes in adhesion of the cellular coat of the oocytes, haemorrhage between the oocyles, intravascular haemolysis in some 
ovarian blood vessels, aggregations of haemosiderin between the oocytes and separation of the follicular layers from the oocytes were observed.

The observed histopathological alterations in the testes and ovaries of the studied fish may reduce the ability of fish to reproduce. It is well known that water pollution has a serious inhibitory effect on fish reproduction (Lesniak and Ruby, 1982, Chang and Plumb, 1996 and Mohamed, 2001a) resulting in a decrease in their abundance and, consequently, a decline in fish species diversity.

Along its course, the Nile receives sewage, agricultural and industrial drainage water from about 37 main drains (Aboul-Ela et al., 1990 ) and the level of pollution increases upward from south to north. The Nile water from Damietta branch $\left(2110\right.$ million $\left.\mathrm{m}^{3}\right)$ mixed with the drainage water from El-Serw and Hadous drains (2050 million $\mathrm{m}^{3}$ ) are the source of water of El-Salam canal.

In previous studies on El-Salam canal, Abdel-Baky (2001) reported that El-Salam canal is contaminated with $\mathrm{Cu}(0.018 \mathrm{mg} / \mathrm{l})$, $\mathrm{Pb}(0.045 \mathrm{mg} / \mathrm{l}), \mathrm{Zn}(3.09 \mathrm{mg} / \mathrm{l})$ and $\mathrm{Mn}(0.07 \mathrm{mg} / \mathrm{l})$. Also, he found that the concentrations of $\mathrm{Pb}$ and $\mathrm{Zn}$ in the liver, kidney, gonads and gills of Clarias gariepinus exceeded the maximum permissible limit. Similarly, Bahnasawy (2001) reported that El-Salam canal is polluted with $\mathrm{Cu}, \mathrm{Zn}, \mathrm{Pb}$ and $\mathrm{Mn}(0.04,0.15,0.09$ and $0.09 \mathrm{mg} / \mathrm{l}$, respectively). He found that the gills, kidney and gonads (especially ovaries) of Clarias gariepinus had high amounts of heavy metal accumulation ( $\mathrm{Cu}, \mathrm{Zn}, \mathrm{Pb}$ and $\mathrm{Mn}$ ). Rabeh (2001) showed a remarkable increase in the bacteria indicative of sewage pollution in El-Salam canal. Sabae and Abdel-Satar (2001) recorded high concentrations of ammonia $(0.62-5.27 \mathrm{mg} / \mathrm{l}), \mathrm{Fe}(0.33-4.76 \mathrm{mg} / \mathrm{l})$, Mn $(27.06-223.36 \mu \mathrm{g} / \mathrm{l}), \mathrm{Zn}(6.92-56.71 \mu \mathrm{g} / \mathrm{l}), \mathrm{Cu}(2.98-54.56$ $\mu \mathrm{g} / \mathrm{l})$ and $\mathrm{Pb}(12.94$ - $53.06 \mu \mathrm{g} / \mathrm{l})$ in El-Salam canal during four successive seasons from autumn 1999 to summer 2000. They also recorded high bacterial counts $\left(72 \times 10^{3}-90 \times 10^{4}\right.$ cells $\left./ \mathrm{ml}\right)$ in ElSalam canal.

Therefore, the histopathological alterations observed in the gills, liver, kidneys and gonads of the studied fish may be attributed to the effects of the agricultural, industrial and sewage wastes discharge into El-Salam canal.

The histopathological changes observed in the gills of the studied fish, collected from El-Salam canal, are in agreement with those observed in Fundulus heteroclitus exposed to cadmium 


\section{HISTOPATHOLOGICAL STUDIES ON SOME ORGANS OF O. NILOTICUS, T. ZILLII AND S. SCHALL}

(Gardner and Yevich, 1970), in channel catfish infected with channel catfish virus disease (Major et al., 1975), in Thymallus arcticus infected with ectoparasite monogenetic trematode (Wobeser et al., 1976), in steelhead trout, Salmo gairdneri exposed to nitrite (Wedemeyer and Yasutake, 1978), in immature rainbow trout exposed to crude oil (Enghelhardt et al., 1981), in Ictalurus punctatus exposed to a combination of ammonia and low levels of monochloramine (Mitchell and Cech, 1983), in Tilapia nilotica exposed to lead acetate, mercuric chloride and cadmium chloride (Balah et al., 1993), in carp (Cyprinus carpio) exposed to 20 and $50 \%$ sewage (Kakuta and Murachi, 1997), in Tilapia zillii exposed to phenol (Marie et al., $1997 \mathrm{a} \& \mathrm{~b}$ ), in Salmo trutta exposed to iron sulphate (Dalzell and Macfarlane, 1999) and in Oreochromis niloticus exposed to pesticides, reldan, roundup and lannate (Mohamed, 1999).

Also, the histopathological alterations observed in the liver of the studied fish are similar to those observed by Desai et al. (1984) in Tilapia mossambica exposed to monocrotophos, Heidemarie and Peters (1985) in ruffe, Gymnocephalus cernua, collected from Elbe Estuary contaminated by domestic, industrial and agricultural pollutants, Aly et al. (1992) in Tilapia nilotica exposed to fluorine and sulphur emitting from factory of fertilizer, Mourad et al. (1999) in Tilapia zillii exposed to lindane and Mohamed (2001b) in Oreochromis niloticus and Tilopia zillii collected from the southern region of Lake Manzalah contaminated with domestic, industrial and agricultural pollutants.

Moreover, the histopathological changes observed in the kidneys of the studied fish are similar to those observed in plaice, Pleuronectes platessa, exposed to crude oil (Haensly et al., 1982), in European eels, Anguilla anguilla, infected with the parasite Myxidium giardi Cépède (Ventura and Paperna, 1984), in Tilapia nilotica exposed to fluorine and sulphur emitting from factory of fertilizer (Aly et al., 1992), in carp, Cyprinus carpio, exposed to 20 and $50 \%$ sewage (Kakuta and Murachi, 1997), in Tilapia zillii exposed to phenol (Marie et al., 1997b) and in Oreochromis niloticus exposed to pesticides, reldan, roundup and lannate (Mohamed, 1999).

Similarly, the histopathological alterations observed in the gonads of the studied fish are in agreement with those observed in Salmo gairdneri exposed to cyanide (Sylvia et al., 1979), in Puntius conchonius exposed to zinc (Kumar and Pant, 1984), in Oreochromis mossambicus exposed to malathion (Shukla et al., 1984), in winter flounder and cod infected with hemoflagellate Trypanosoma 
murmanensis and then exposed to Venezuelan crude oil (Khan, 1987), in Heteropneustes fossilis exposed to textile-mill effluent (Murugesan and Haniffa, 1992), in Oreochromis niloticus infected by Streptococcus sp. (Chang and Plumb, 1996) and in Tilapia zillii exposed to phenol (Mohamed, 2001a).

The results indicated that the histopathological alterations were more severe during winter and this may be attributed to the types of pesticides in the agricultural wastes dumping to the water body of El-Salam canal during winter. Also, the histopathological changes were more severe in Oreochromis niloticus than Tilapia zillii and Synodontis schall and this may be attributed to the fact that $T$. zillii and Synodontis schall can adapt easily to variations in the ecological conditions of the canal.

It could be concluded that the environmental conditions of ElSalam canal induce histopathological changes in the gills, liver, kidneys and gonads of Oreochromis niloticus, Tilapia zillii and Synodontis schall. Consequently, it is recommend to subject the drainage waters discharged into El-Salam canal to technical treatment that fulfill its safety.

\section{REFERENCES}

Abdel-Baky, T. E. (2001). Heavy metals concentrations in the catfish Clarias gariepinus (Burchell, 1822) from River Nile, ElSalam canal and Lake Manzala and their impacts on cortisol and thyroid hormones. Egypt. J. Aquat. Biol. \& Fish., 5(1): $79-98$.

Aboul-Ela, T. A. ; Fayed, S. E. and Ghazy, M. M. (1990). Zooplankton as a parameter of pollution of the Nile water in Egypt. Proc. Zool. Soc. A.R.E., 21: 203-217.

Aly, S. R. ; Ibrahim, Th. A. and Mahmoud, A. Z. (1992). Hazardous effect of some industrial pollutant on Tilapia nilotica (Oreochromis niloticus). Assiut Vet. Med. J., 27(54): 189 200.

Bahnasawy, M.H. (2001). Levels of heavy metals in catfish, Clarias gariepinus from different habitats and their effects on some biochemical parameters. Egypt. J. Aquat. Biol. \& Fish., 5(1): $99-125$. 


\section{HISTOPATHOLOGICAL STUDIES ON SOME ORGANS OF O. NILOTICUS, T. ZILLII AND S. SCHALL}

Balah, A. M. ; El-Bouhy, Z. M. and Easa, M. E. (1993). Histologic and histopathologic studies on the gills of Tilapia nilotica (Oreochromis niloticus) under the effect of some heavy metals. Zag. Vet. J., 21(3): $351-364$.

Bass, M. L. ; Berry, C. R. Jr. and Heath, A. G. (1977). Histopathological effects of intermittent chlorine exposure on blue gill (Lepomis macrochirus) and rainbow trout (Salmo gairdneri). Water Res., 11: 731 - 735 .

Chang, P. H. and Plumb, J. A. (1996). Histopathology of experimental Streptococcus sp. infection in Tilapia, Oreochromis niloticus (L.) and channel catfish, Ictalurus punctalus (Rafinesque). J. Fish Dis., 19: 235 - 241.

Cormier, S. M. (1986). Fine structure of hepatocytes and hepatocellular carcinoma of the atlantic tonicod, Microgadus tomcod (Walbaum). J. Fish Dis., 9: 179 - 194.

Couch, J. A. (1975). Histopathologic effects of pesticides and related chemicals on the livers of fishes. In: The pathology of fishes (W.E. Ribelin and G. Migaki, eds.). Univ. Wisconsin Press, Madison, Wisconsin, pp. $559-584$.

Dalzell, D. J. and Macfarlane, N. A. (1999). The toxicity of iron to brown trout and effects on the gills: A comparison of two grades of iron sulphate. J. Fish Biol., 55: $301-315$.

Desai, A. K. ; Joshi, U. M. and Ambadkar, P. M. (1984). Histological observations on the liver of Tilapia mossambica after exposure to monocrotophos, an organophosphorous insecticide. Toxicol. Lett., $21: 325-331$.

DiMichele, L. and Taylor, M. (1978). Histopathological and physiological responses of Fundulus heteroclitus to naphthalene exposure. J. Fish. Res. Bd. Can., 35: 10601066. 
Dixon, D. G. and Leduc, G. (1981). Chronic cyanide poisoning of rainbow trout and its effects on growth, respiration and liver histopathology. Arch. Environm. Contam. Toxicol., 10: 117 $-131$.

Enghelhardt, F. R. ; Wong, M. P. and Duey, M. E. (1981). Hydromineral balance and gill morphology in rainbow trout; Salmo gairdneri, acclimated to fresh and sea water, as affected by petroleum exposure. Aquat. Toxicol., 1: $175-$ 186.

Gabr, S. A. (1990). Histopathological changes induced in the liver and kidney of Tilapia nilotica by neopybuthrin. Sci. J. Fac. Sci. Monou. Univ., 4: $17-27$.

Gardner. G. R. and Yevich, P. P. (1970). Histological and hematological responses of an estuarine teleost to cadmium. J. Fish. Res. Bd. Can., 27: 2185-2196.

Haensly, W. E. ; Neiff, J. M. ; Sharp, J. R. ; Morris, A. C. ; Bedgood, M. F. and Boem, P. D. (1982). Histopathology of Pleuronectes platessa from Aber Wrach and Aber Benoit, Brittany, France: long-term effects of the Amoco-Cadiz crude oil spill. J. Fish. Dis., 5: 365-392.

Hamza, S. M. ; Shaaban, F. E. ; Ghoneim, M. H. ; Diab, A. S. ; Badran, A. F. and El-Fara, H.A. (1996). Histopathological, Biochemical, Immunotoxic and Residual studies of Clarias lazera exposed to bayluscide molluscicide. Egypt. J. Immun., 3(1): $123-130$.

Heidemarie, K. and Peters, N. (1985). Pathological conditions in the liver of ruffe, Gymnocephalus cernua (L.), from the Elbe estuary. J. Fish Dis., 8: 13-24.

Issa, M. M. and Gabr, S. A. (1989). The effect of repeated increasing sublethal doses of diazinon on the liver of Tilapia nilotica, light and electron microscopial study. Bull. Fac. Sci. Assi. Univ., $18(1): 23-47$. 
Kadry, S. M. and Abdel Mageid, S. A. (1995). Histological and enzyme histochemical studies on the chronic effect of endosulfan on the liver of Clarias lazera. Proc. Zool. Soc. A.R.E., 26: $151-164$.

Kakuta, I. and Murachi, S. (1997). Physiological response of carp, Cyprinus carpio, exposed to raw sewage containing fish processing wastewater. Environ. Toxicol. Water Qual., 12:1 $-9$.

Khan, R. A. (1987). Effects of chronic exposure to petroleum hydrocarbons on two species of marine fish infected with a hemoprotozoan, Trypanosoma murmanensis. Canada J. Zool., 65: 2703-2709.

Kirubagaran, R. and Joy, K. P. (1992). Toxic effects of mercury on testicular activity in the freshwater teleost, Clarias batrachus (L.). J. Fish Biol., 41: $305-315$.

Kumar, S. and Pant, S. (1984). Comparative effects of the sublethal poisoning of zinc, copper and lead on the gonads of the teleost Puntius conchonius Ham. Toxicol. Lett., 23: 189 194.

Kumar, S. and Srivastava, G. J. (1980). The effect of sodium chloride on kidney and corpuscles of stannius of Channa punctatus. Zool. Beitr., 26: $13-16$.

Leino, R. L. ; Wilkinson, P. and Anderson, J. (1987). Histopathological changes in the gills of pearl dace, Semotilus margarita and fathead minnows, Pimephales promleas, from experimentally acidified Canadian Lakes. Can. J. Fish. Aquat. Sci., 44: 126 - 134.

Lesniak, J. A. and Ruby, S. M. (1982). Histological and quantitative effects of sublethal cyanide exposure on oocyte development in rainbow trout. Arch. Environm. Contam. Toxicol., $11: 343-352$. 
Li, M. F. ; Traxler, G. S. and Clyburne, S. (1978). Histopathological and hematological changes in mummichogs, Fundulus heteroclitus, infected by a pseudomonad. J. Fish. Res. Bd. Can., 35: $1376-1381$.

Major, R. D. ; McCraren, J. P. and Smith, C. E. (1975). Histopathological changes in channel catfish (Ictalurus punctatus) experimentally and naturally infected with channel catfish virus disease. J. Fish. Res. Bd. Can., 32: 563 -567 .

Marie, M. A. S. ; Aboul Ezz, A. S. and Mohamed, F. A. S. (1997a). Toxicological and pathological effects of phenol on Oreochromis niloticus and Tilapia zillii. Egypt. J. Zool., 29: $295-319$.

Marie, M. A. S. ; Aboul Ezz, A.S. and Mohamed, F. A. S. (1997b). Studies on the toxic effects of phenol on the teleosti, Tilapia zillii (Gervais, 1848). Egypt. J. Zool., 29: $321-347$.

Mitchell, S. J. and Cech, J. J. Jr. (1983). Ammonia-caused gill damage in channel catfish (Ictalurus punctatus): Confounding effects of residual chlorine. Can. J. Fish. Aquat. Sci., 40: 242-247.

Mohamed, F. A. E. S. (1999). Physiopathological study on the effects of some pesticides on Oreochromis niloticus. Ph.D. Thesis, Fac. Sci., Cairo Univ., Cairo, Egypt.

Mohamed, F. A. S. (2001a). Effects of phenol on the histological structures of the intestine and gonads of the freshwater teleost Tilapia zillii (Gervais, 1848). Egypt. J. Aquat. Biol. \& Fish., 5(1): $195-223$.

Mohamed, F. A. S. (2001b). Impacts of environmental pollution in the southern region of Lake Manzalah, Egypt, on the histological structures of the liver and intestine of Oreochromis niloticus and Tilapia zillii. J. Egypt. Acad. Soc. Environ. Develop., 2(2): 25 - 42. 


\section{HISTOPATHOLOGICAL STUDIES ON SOME ORGANS OF O. NILOTICUS, T. ZILLII AND S. SCHALL}

Mourad, M. ; Abd Allah, M. and Abd-Allah, A. (1999). Occurrence of lindane and its effects on some hematological and histological aspects of Tilapia zillii (Gerv.). Bull. Nat. Inst. Oceanogr. \& Fish., A.R.E., 25: 237-251.

Murugesan, A. G. and Haniffa, M. A. (1992). Histopathological and histochemical changes in the oocytes of the air-breathing fish Heteropneustes fossilis (Bloch) exposed to textile-mill effluent. Bull. Env. Contam. Toxicol., 48: 929 - 936.

Naidu, K. A. ; Naidu, K. A. and Ramamurthi, R. (1983). Histological observations in gills of the teleost Sarotherodon mossambicus with reference to mercury toxicity. Ecotoxico. Environm. Safety, 7: 455-462.

Rabeh, S. A. (2001). Monitoring of microbial pollution in El-Salam Canal Egypt. J. Egypt. Acad. Soc. Environ. Develop., 2(1): $117-127$.

Ram, R. N. and Singh, S. K. (1988). Carbofuran - induced histopathological and biochemical changes in liver of the teleost fish; Channa punctatus (Bloch). Ecotoxicol. Environ. Safety, 16(3): 194-201.

Sabae, S. Z. and Abdel-Satar, A. M. (2001). Chemical and Bacteriological studies on El-Salam Canal, Egypt. J. Egypt. Acad. Soc. Environ. Develop., 2(1): 173 - 197.

Sastry, K. V. and Malik, P. V. (1979). Studies on the effect of dimercon on the digestive system of a freshwater fish; Channa punctatus. Arch. Environ. Contam. Toxicol., 8: 397 $-407$.

Sastry, K. V. and Sharma, K. (1981). Diazinon-induced histopathological and haematological alterations in a freshwater teleost, Ophiocephalus punctatus. Ecotoxicol. Environ. Safety, 5: $329-340$. 
Shukla, L. ; Shrivastava, A. ; Merwani, D. and Pandey, A. K. (1984). Effect of sublethal malathion on ovarian histophysiology in Sarotherodon mossambicus. Comp. Physiol. Ecol., 9: 13 17.

Singh, H. (1989). Interaction of xenobiotics with reproductive endocrine functions in a protogynous teleost, Monopterus albus. Mar. Env. Res., 28: 285-289.

Sylvia, M. R. ; Dixon, D. G. and Leduc, G. (1979). Inhibition of spermatogenesis in rainbow trout during chronic cyanide poisoning. Arch. Environm. Contam. Toxicol., 8: 533-544.

Ventura, M. T. and Paperna, I. (1984). Histopathology of Myxidium giardi Cepede, 1906 infection in European eels, Anguilla anguilla L., in Portugal. Aquacult., 43: $357-368$.

Wedemeyer, G. A. and Yasutake, W. T. (1978). Prevention and treatment of nitrite toxicity in juvenile steelhead trout (Salmo gairdneri). J. Fish. Res. Bd. Can., 35: 822 - 827.

Wobeser, G. ; Kratt, L. F. ; Smith, R. J. and Acompanado, G. (1976). Proliferative branchiitis due to Tetraonchus rauschi (Trematoda: Monogenea) in captive Arctic grayling (Thymallus arcticus). J. Fish. Res. Bd. Can., 33:1817-1821.

Wolf, K. ; Herman, R. L. and Carlson, C. P. (1972). Fish viruses: histopathologic changes associated with experimental channel catfish virus disease. J. Fish. Res. Bd. Can., 29: 149 -150 .

Yokote, M. (1982). Digestive system. In: An atlas of fish histologynormal and pathological features (T. Hibiya, ed.). pp. 74-93, Kodanisha Ltd.; Tokyo. 


\section{EXPLANATION OF FIGURES}

Fig. (1): Sections of gills of fish showing:

(A): control Oreochromis niloticus, Tilapia zillii and Synodontis schall (X100).

(B): proliferative changes in the epithelium of gill filaments and secondary lamellae (O. niloticus, spring 2000) (X 100).

(C): proliferative changes in the epithelium of gill filaments and secondary lamellae ( $S$. schall, winter 2001) ( X 400).

(D) \& (E): proliferative changes in the epithelium of gill filaments and secondary lamellae (O. niloticus, winter 2001) (X100 $\& 400$, respectively).

(F): degenerative and necrotic changes in gill filaments $(O$. niloticus, spring 2000) (X 400).

Fig. (2): Sections of gills of fish showing:

(A) \& (B): severe degenerative and necrotic changes in gill filaments and mucus accumulation between gill filaments $(O$. niloticus and T. zillii, respectively, winter 2001) (X400).

(C) \& (D): dilation and congestion in the blood vessels of gill filaments (T. zillii, winter 2001 and $O$. niloticus, spring 2000 , respectively) (X 400).

(E): nodular proliferation in gill filaments (T. zillii, summer 2000) (X 100).

(F): intravascular haemolysis and dilation in the blood vessels of gill filaments (O. niloticus, winter 2001) (X 400).

(G): $\quad$ edema in secondary lamellae (O. niloticus, winter 2001)( $\mathrm{X} 100$ ).

Fig. (3): Sections of gills and liver of fish showing:

(A) \& (C): separation of the epithelium of the secondary gill lamellae from the lamellar supporting cells and haemorrhage between gill filaments (O. niloticus, spring 2000) (X 100 $\& 400$, respectively).

(B) \& (D): separation of the epithelium of the secondary lamellae from the lamellar supporting cells ( $S$. schall, summer 2000 and $T$. zillii, winter 2001 , respectively) (X 400).

(E): hepatocytes of control Oreochromis niloticus, Tilapia zillii and Synodontis schall ( X 400). 
Fig. (4): Sections of liver of fish showing:

(A): $\quad$ coagulative necrosis (O. niloticus, spring 2000) (X 400).

(B): $\quad$ thrombosis in hepatoportal blood vessels (T. zillii, spring 2000 ) ( X 400).

(C): thrombosis in hepatic blood vessels (O. niloticus, summer 2000) $(X 400)$.

(D): intravascular haemolysis and dilation in hepatoportal blood vessels (T. zillii, summer 2000) ( X 100).

(E): intravascular haemolysis and dilation in hepatic blood vessels (O. niloticus, winter 2001) (X 100).

(F): dilation of central vein (O. niloticus, spring 2000) (X 400).

Fig. (5): Sections of liver of fish showing:

(A): destruction of hepatoportal blood vessels ( $O$. niloticus, spring 2000) (X 400).

(B) \& (C): necrosis between the hepatocytes ( $O$. niloticus, spring 2000 and winter 2001 , respectively) (X 400).

(D): haemorrhage and aggregation of inflammatory cells between the hepatocytes (O. niloticus, spring 2000) (X 400).

(E): haemorrhage between the hepatocytes (O. niloticus, winter2001) (X 400).

(F): dilation and congestion in blood sinusoids (T. zillii, spring 2000) (X 400).

Fig. (6): Sections of liver and kidneys of fish showing:

(A): vacuolar degeneration of the hepatocytes and haemolysis in blood sinusoids (S. schall, spring 2000) (X 400).

(B): vacuolar degeneration of the hepatocytes $(O$. niloticus, spring 2000) (X 400).

(C) \& (D): vacuolar degeneration of the hepatocytes (S. schall, spring 2000 and $O$. niloticus, autumn 2000 , respectively) ( $\mathrm{X}$ 400 ).

(E) \& (F): extensive vacuolar degeneration of the hepatocytes ( $S$. schall and $O$. niloticus, winter 2001 , respectively) (X 400).

(G): kidneys of control Oreochromis niloticus, Tilapia zillii and Synodontis schall ( X 400).

(H): aggregation of inflammatory cells between the renal tubules (S. schall, spring 2000) (X 400). 
Fig. (7): $\quad$ Sections of kidneys of fish showing:

(A): edema in Bowman's capsules ( $O$. niloticus, autumn 2000) (X100).

(B): extensive vacuolar degeneration in the epithelium of renal tubules and dilation of the capillary tubes of renal tubules (O. niloticus, winter 2001 ) (X 400).

(C): dilaton of the capillary tubes of renal tubules (T. zillii, summer 2000) (X 400).

(D): congestion of the capillary tubes of renal tubules ( $S$. schall, autumn 2000) ( X 400).

(E): haemolysis and aggregation of inflammatory cells between renal tubules (O. niloticus, spring 2000) ( $\mathrm{X}$ 400).

(F) \& (G): severe haemolysis between renal tubules $(O$. niloticus and S. schall, respectively, winter 2001) ( X 400).

(H): depletion in the haemopoietic areas (T. zillii, spring 2000) (X 400)

Fig. (8): Sections of kidneys and testes of fish showing:

(A): intravascular haemolysis in renal blood vessels and over population of glomeruli (T. zillii, winter 2001) (X 400).

(B): necrosis between the renal tubules (O. niloticus, winter 2001) (X 400).

(C): vacuolar degeneration in the epithelium of renal tubules (O. niloticus, spring 2000) ( $\mathrm{X} 400$ ).

(D): necrosis between the renal tubules $(O$. niloticus, summer 2000) $(X 400)$.

(E): $\quad$ testes of control Oreochromis niloticus, Tilapia zillii and Synodontis schall ( $\mathrm{X} 400$ ).

Fig. (9): Sections of testes of fish showing:

(A) : coagulative necrosis (O. niloticus, winter 2001) (X 400).

(B): necrosis (O. niloticus, summer 2000) (X 400).

(C) \& (D): degenerative and necrotic changes in the cellular elements of seminiferous tubules $(O$. niloticus, winter 2001 and spring 2000 , respectively) $(X 400)$.

(E): degenerative and necrotic changes in the cellular elements of seminiferous tubules, focal areas of necrosis and sperms between the seminiferous tubules (T. zillii, summer 2000) (X 400). 
Fig. (10): Sections of testes and ovaries of fish showing:

(A) \& (B): seminiferous tubules with a lesser number of sperms or lucent (O. niloticus, spring 2000 and S. schall, autumn 2000 , respectively) (X400).

(C) \& (D): fibrous capsules around seminiferous tubules $(O$. niloticus, winter 2001 and autumn 2000, respectively) (X400)

(E): ovaries of control Oreochromis niloticus, Tilapia zillii and Synodontis schall (X100).

(F) \& (G): separation of the follicular layers from the oocytes $(O$. niloticus, spring 2000 and $S$. schall, summer 2000, respectively) (X400).

$(\mathrm{H})$ : thickening of the ovarian wall ( $T$. zillii, winter 2001) (X400).

Fig. (I1): Sections of ovaries of fish showing:

(A): collapsed and abnormal irregularly shaped oocytes $(O$. niloticus, spring 2000) (X400).

(B): haemorrhage between the oocytes (T. zillii, spring 2000) (X400).

(C): aggregation of haemosiderin between the oocytes $(O$. niloticus, winter 2001) (X400).

(D) \& (E): proliferative changes in the granulosa of the oocytes, resulting in adhesion of the cellular coat of the oocytes $(T$. zillii, spring 2000 and $O$. niloticus, winter 2001, respectively) (X400)

Fig. (12): Sections of ovaries of fish showing:

(A): degenerative and necrotic changes in the oocytes $(O$. niloticus, winter 2001) (X400).

(B): degenerative changes in the oocytes ( $O$. niloticus, spring 2000) (X400).

(C): thrombosis in ovarian blood vessels ( $O$. niloticus, winter 2001) (X400). 


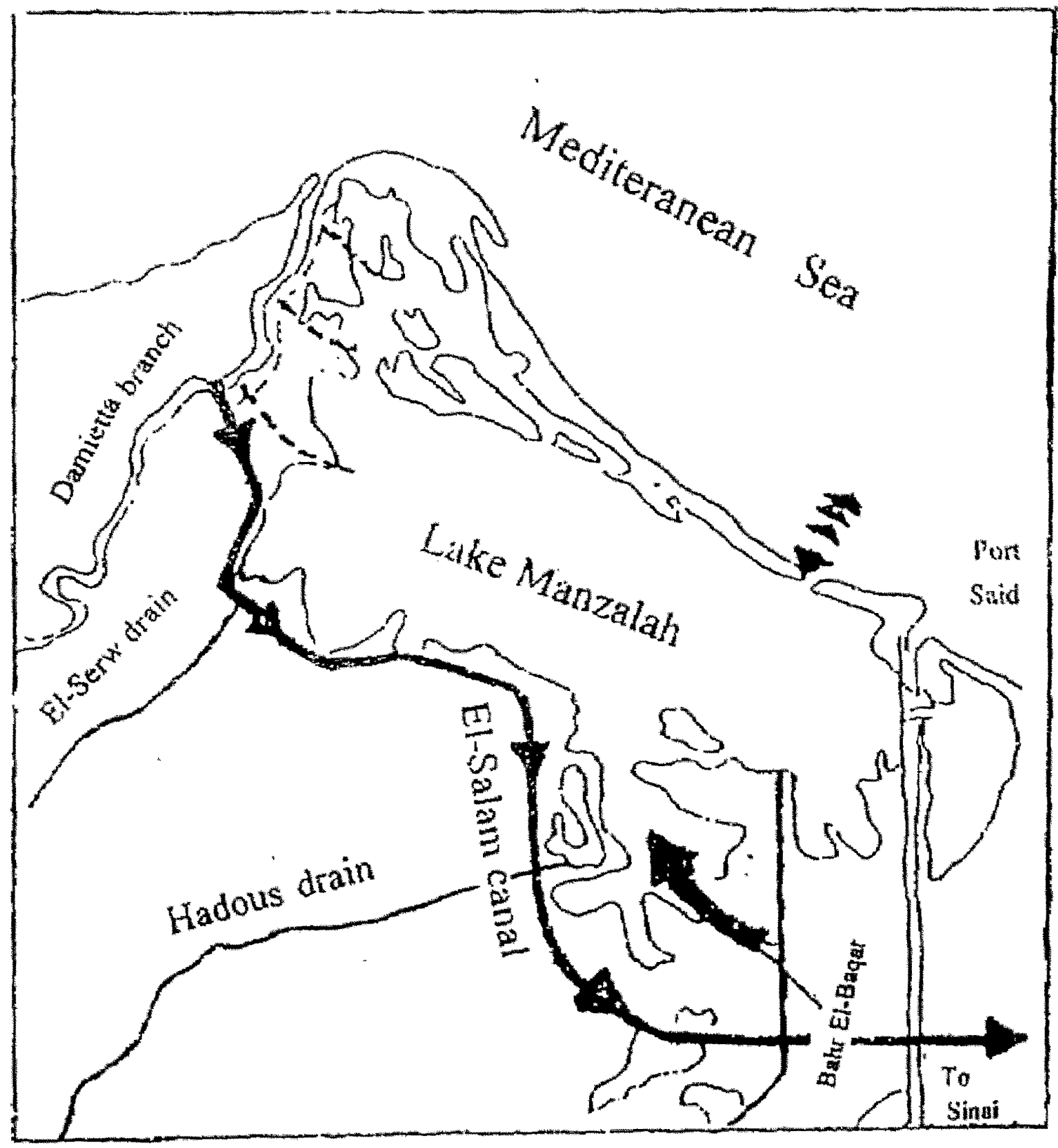




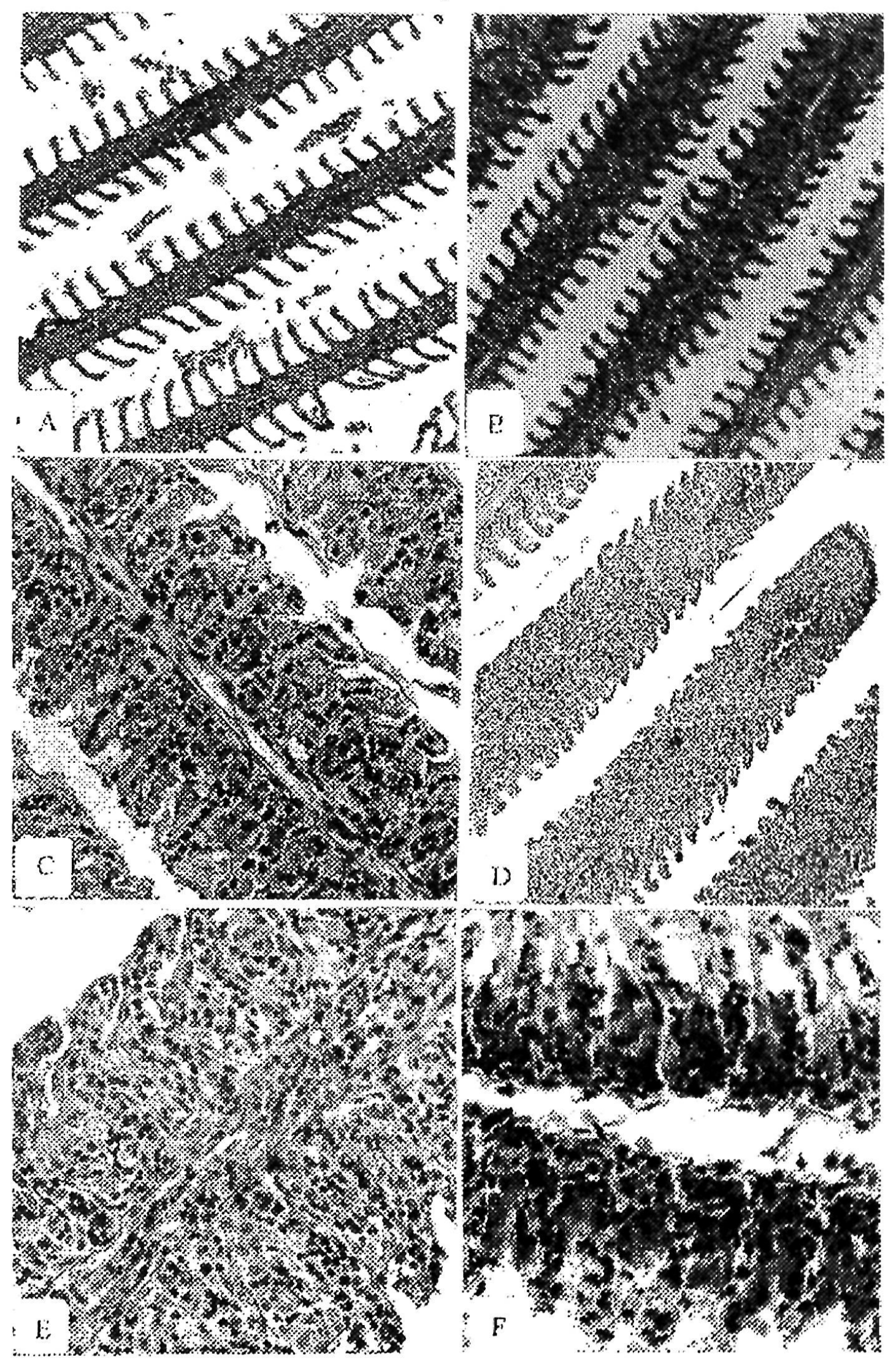

mig. (1) 

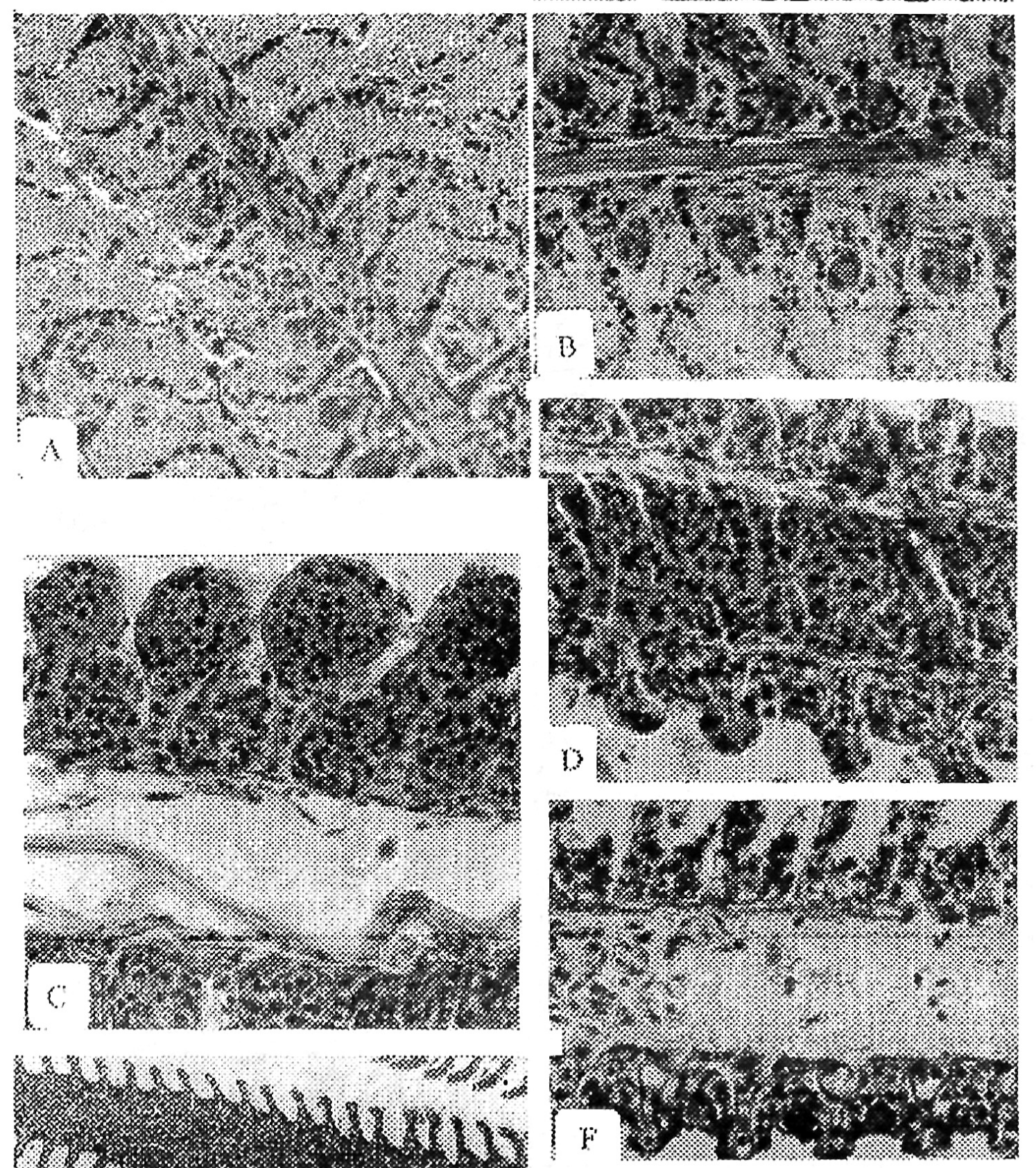

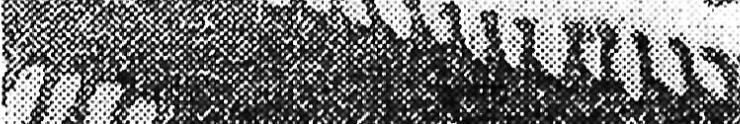

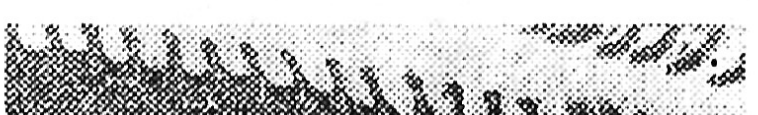
Hinu

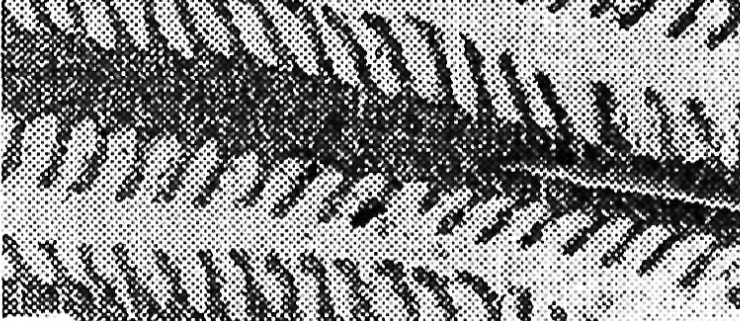

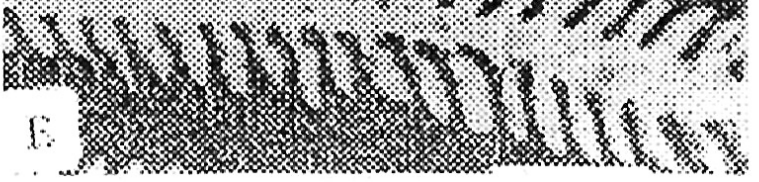

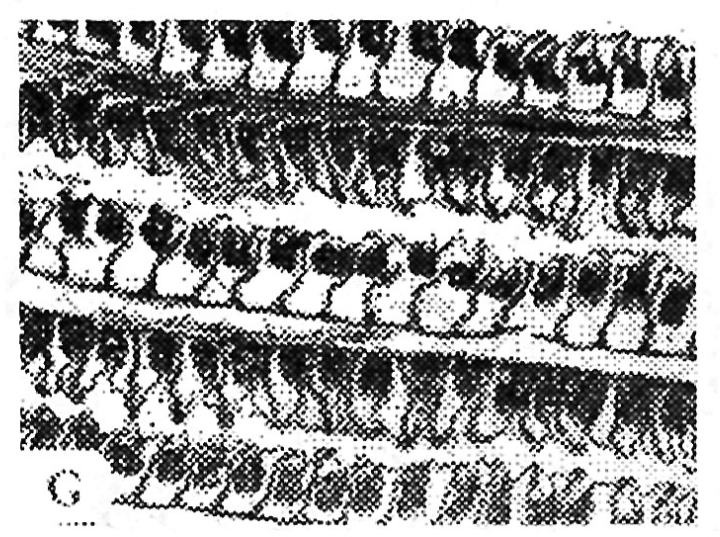

(3) 

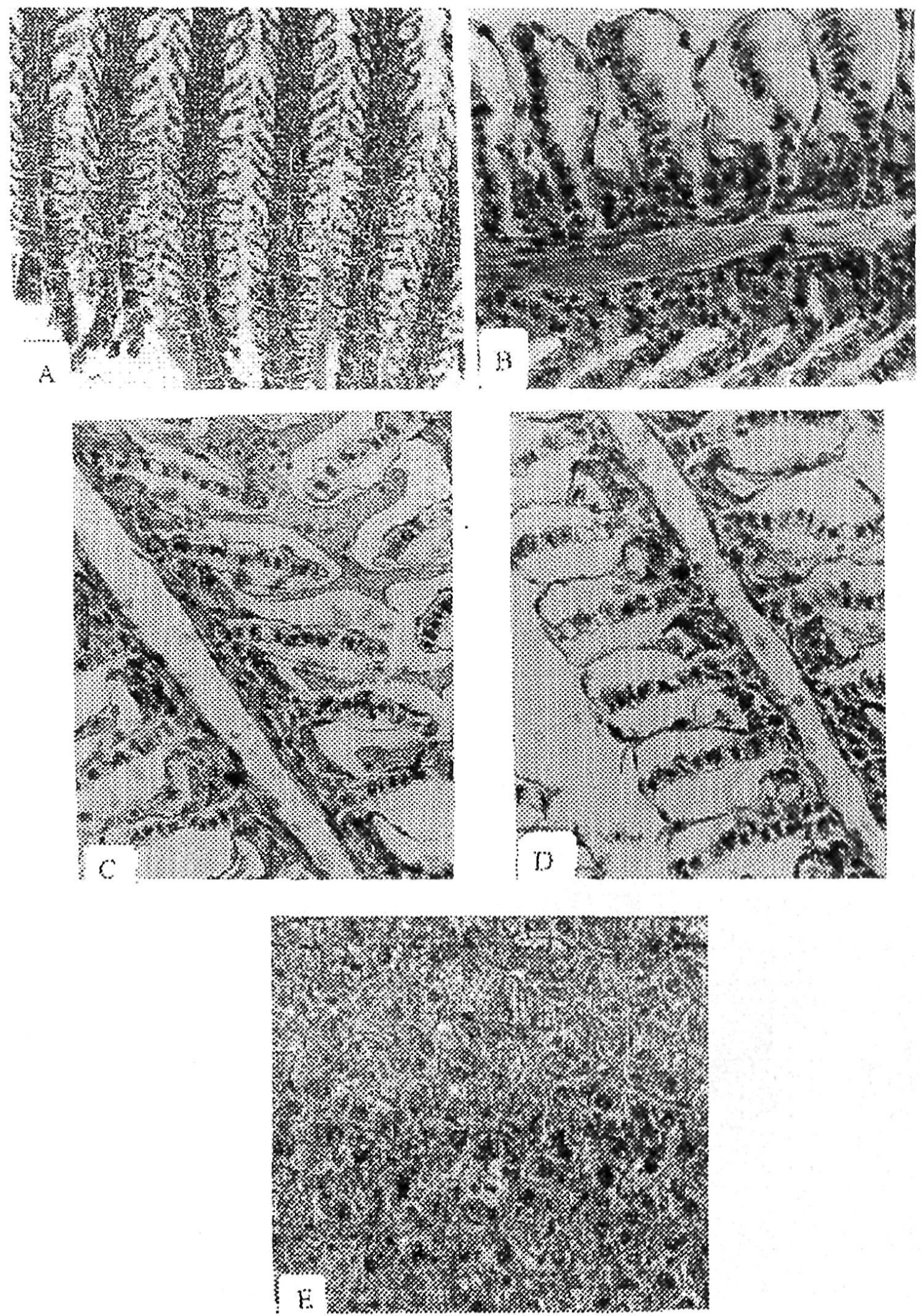

Fig. (3) 

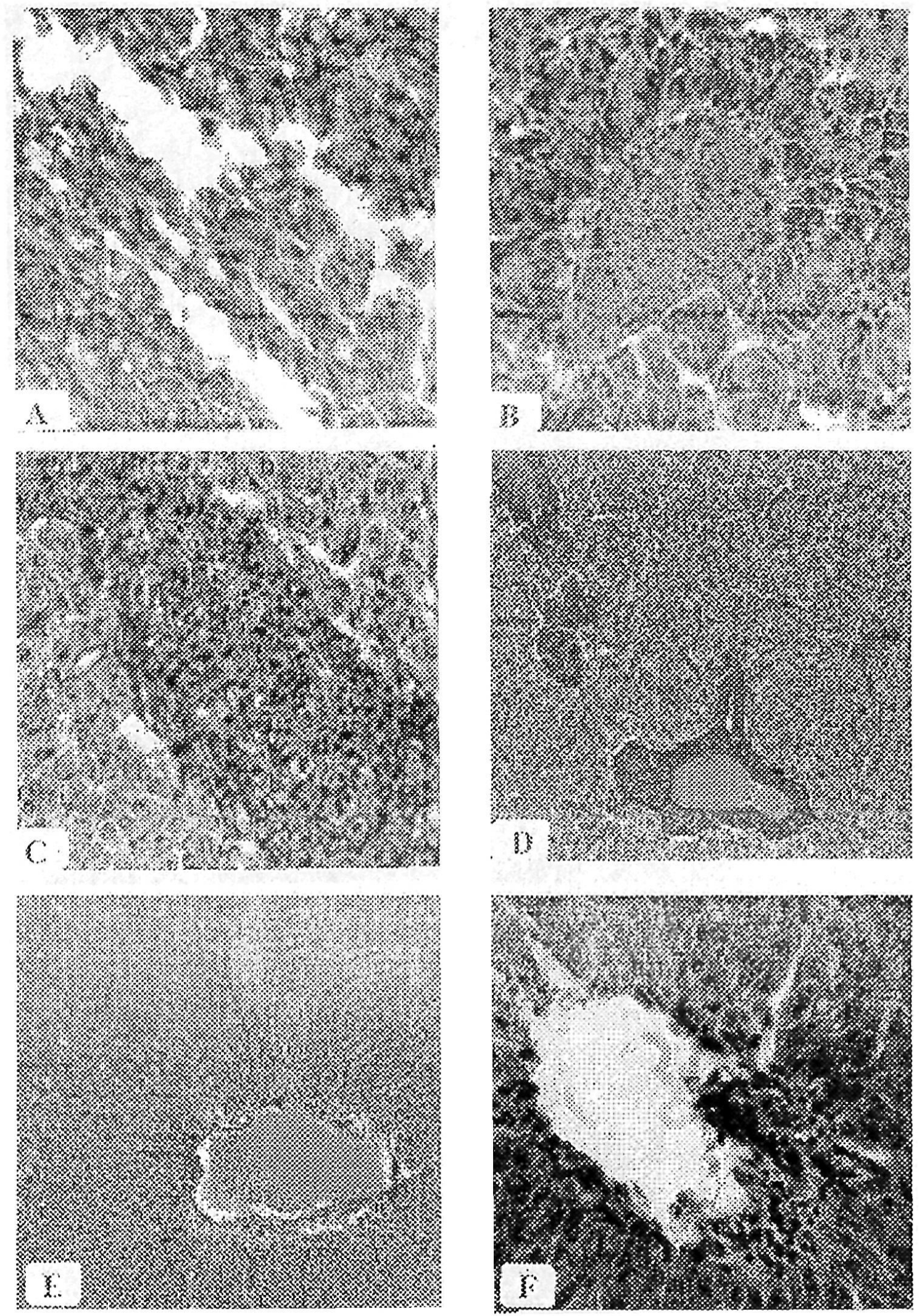

$\mathrm{mig}(4)$ 

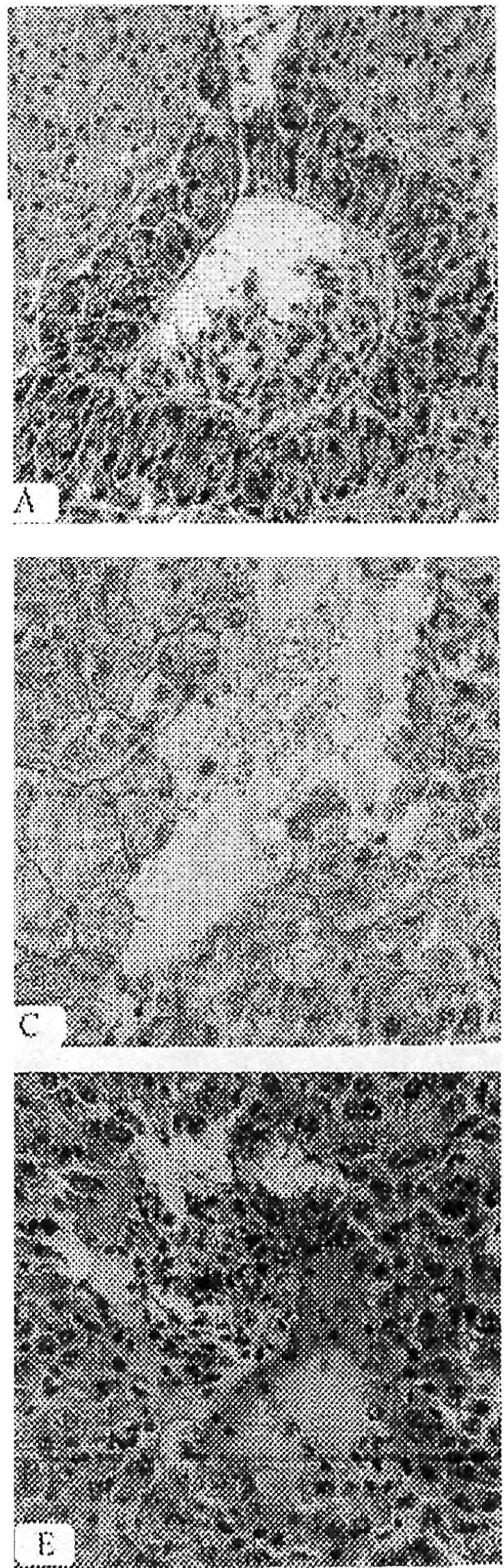
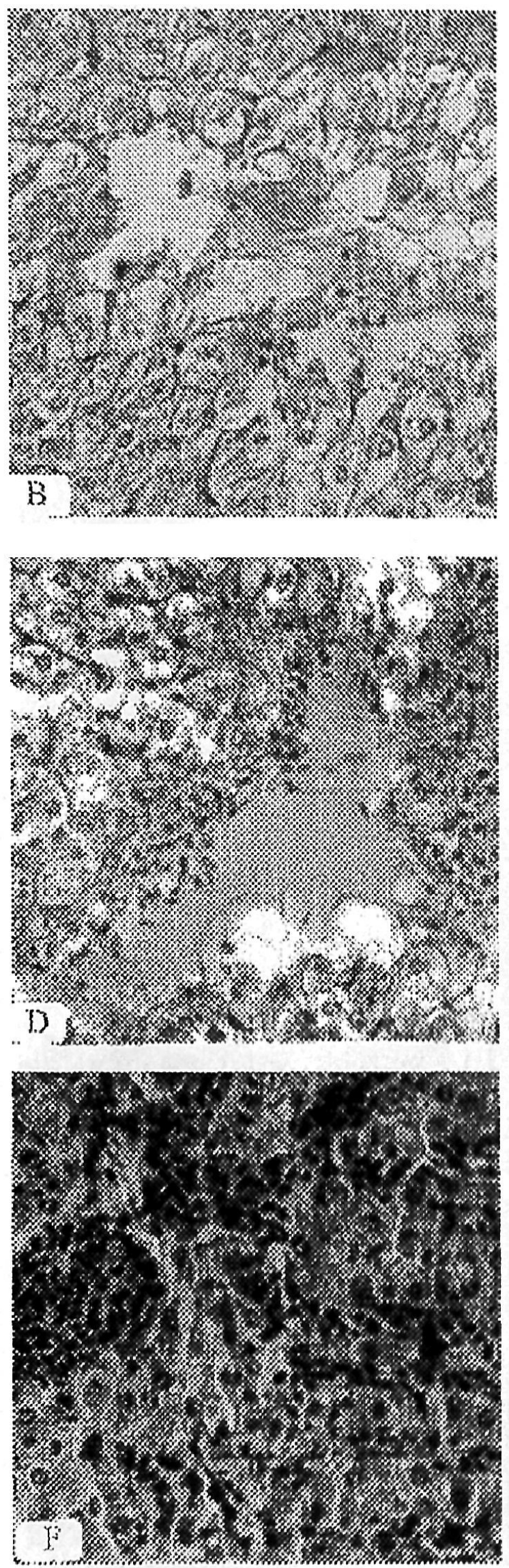


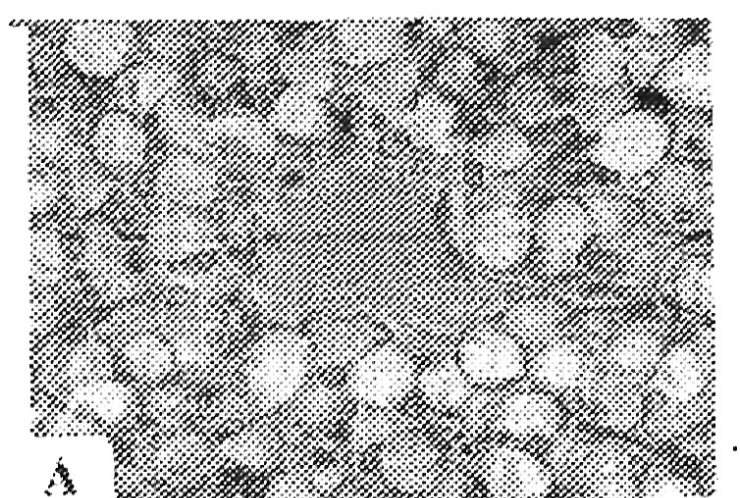

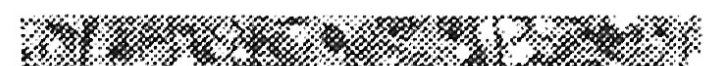
10. 1 \% 16.0.

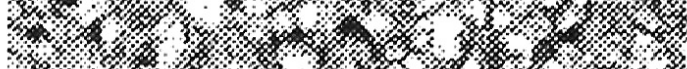

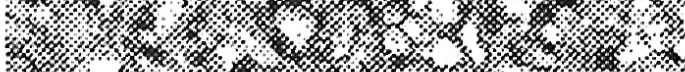

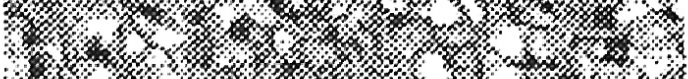

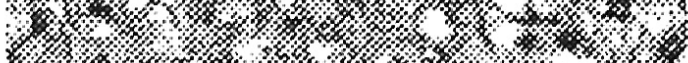
3.

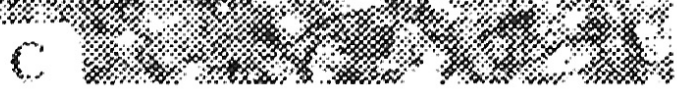
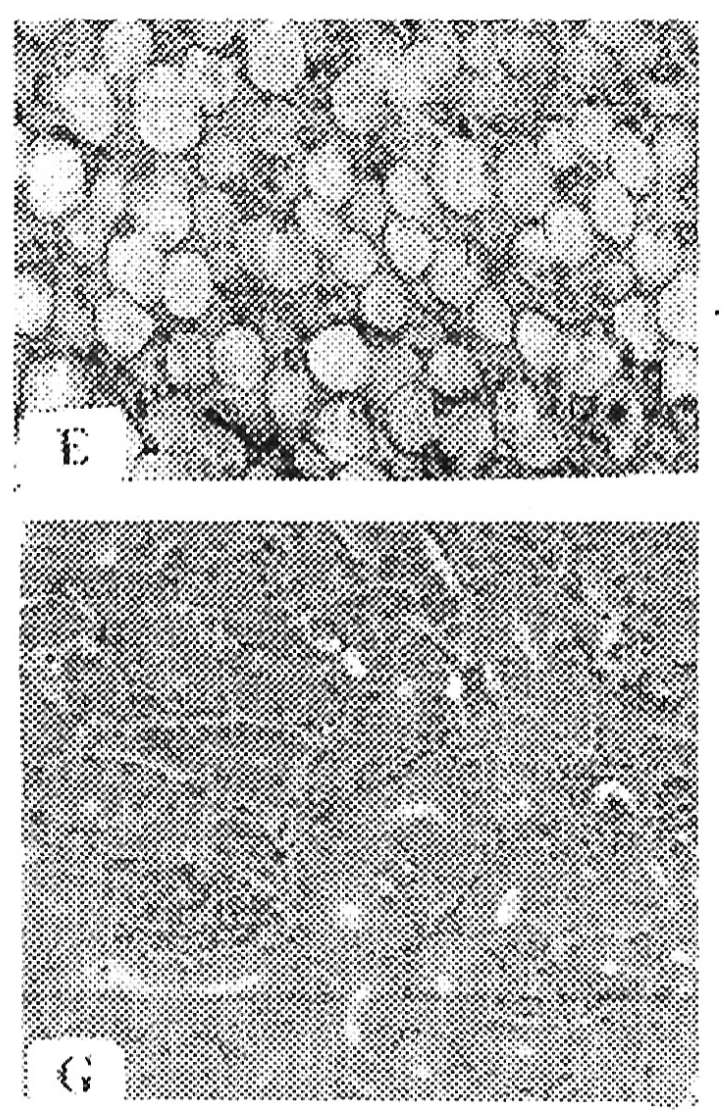
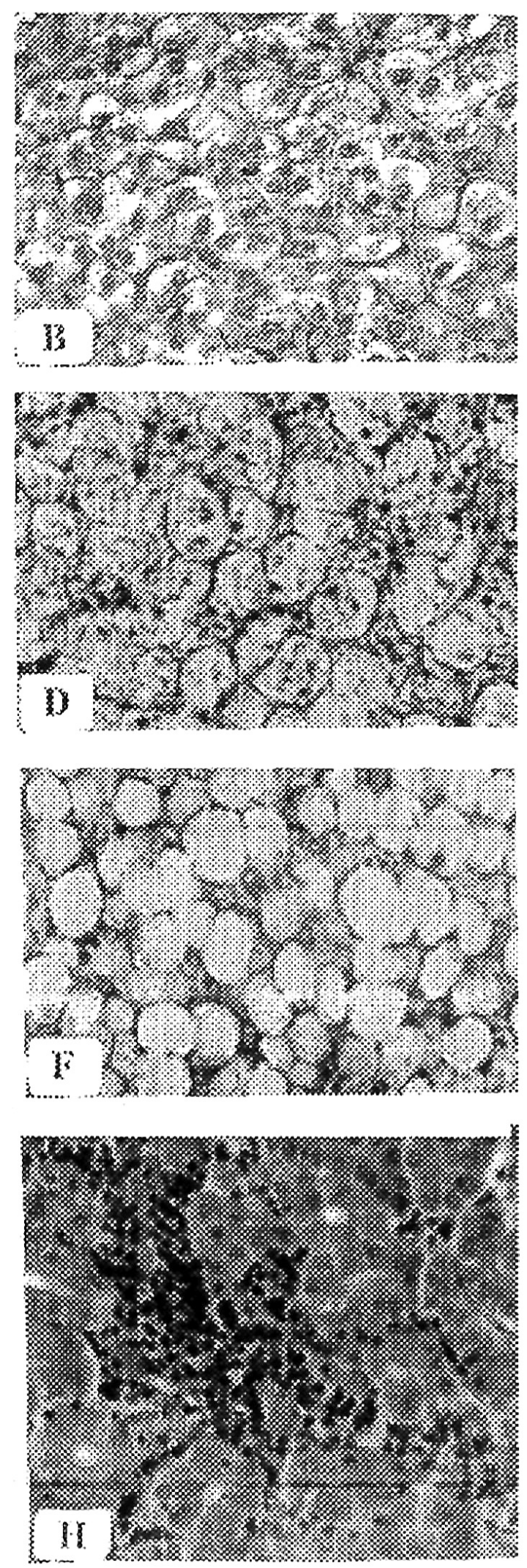

ag $(0)$ 

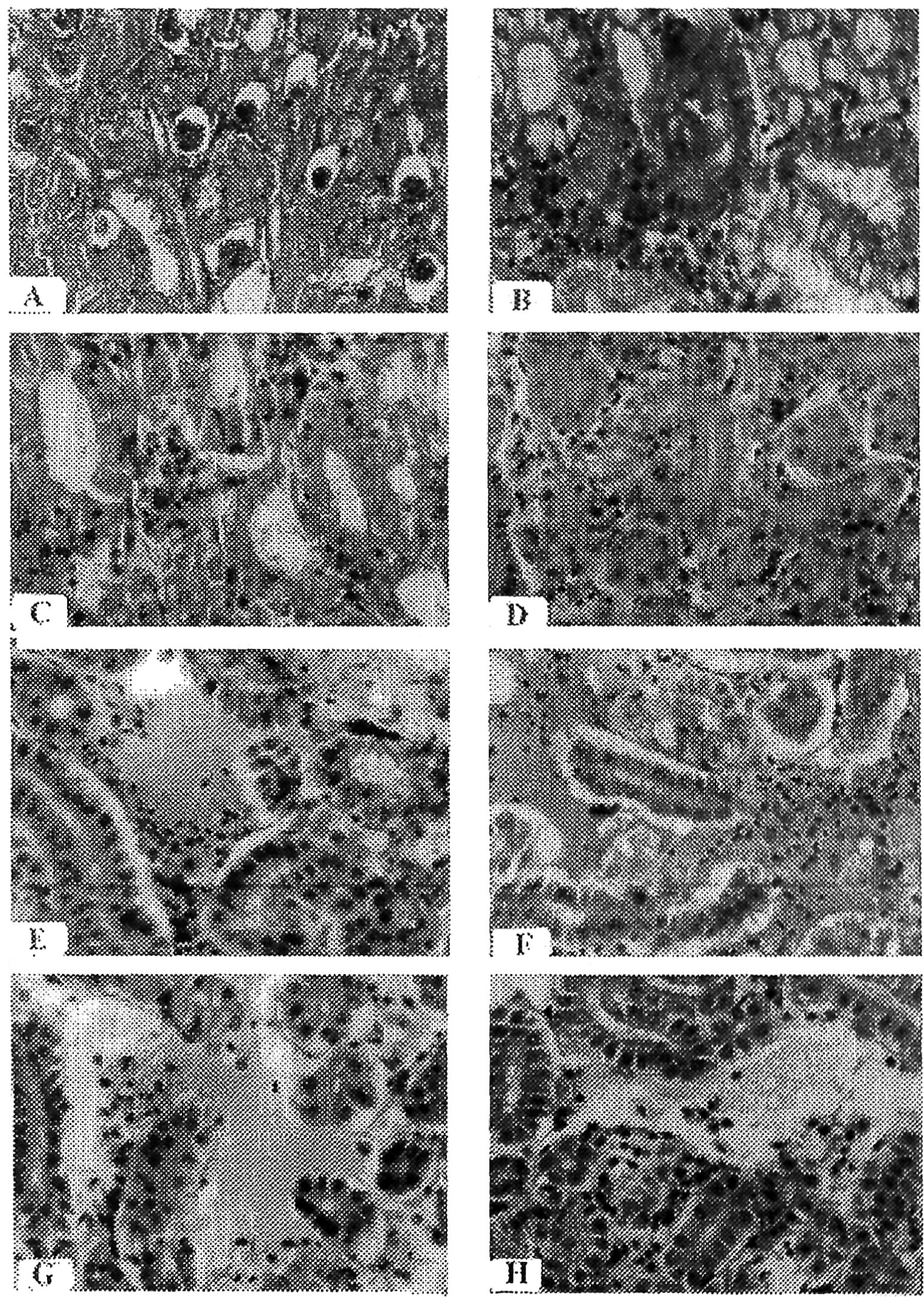

Fis (?) 


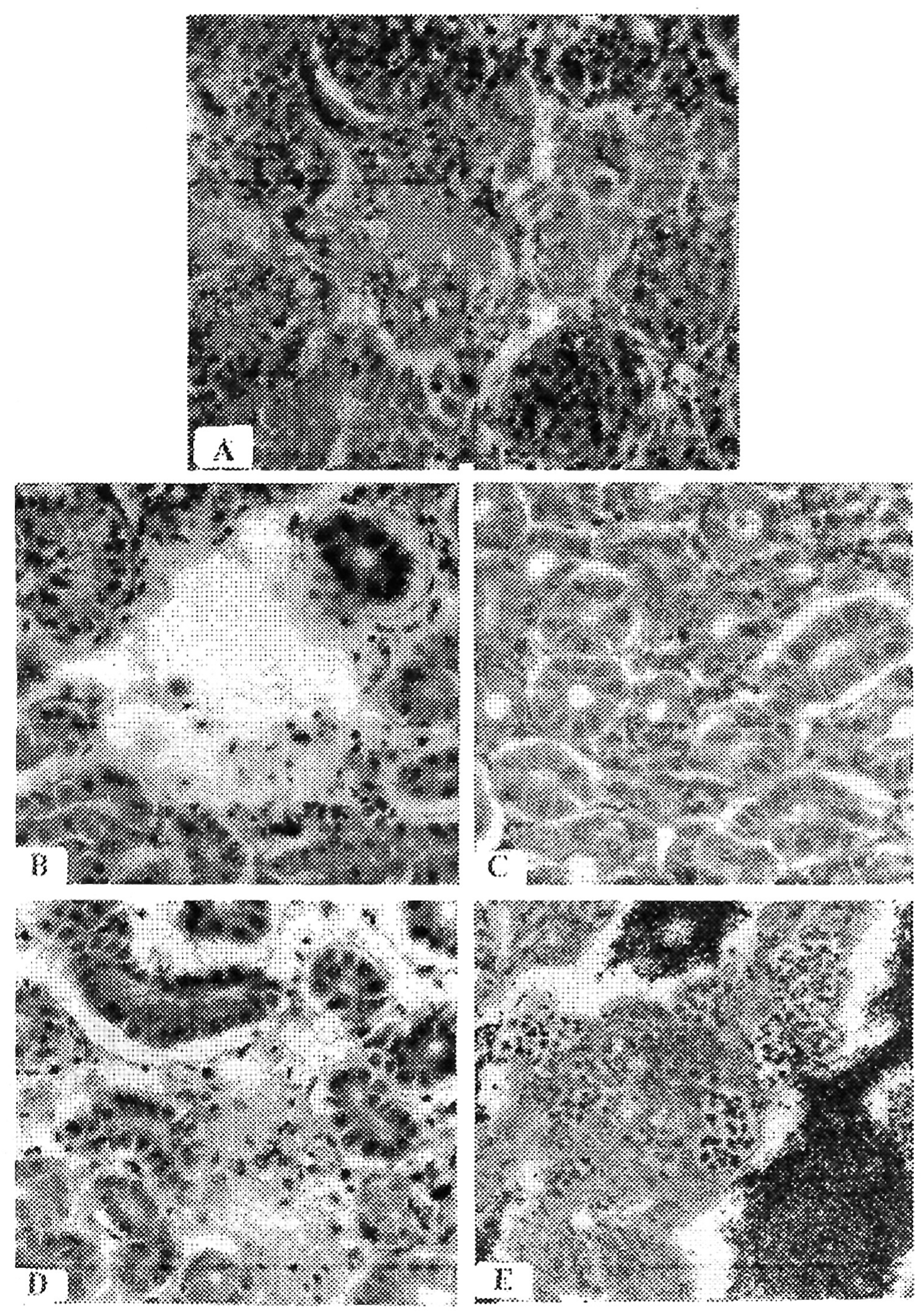

sing $\{$ (n) 

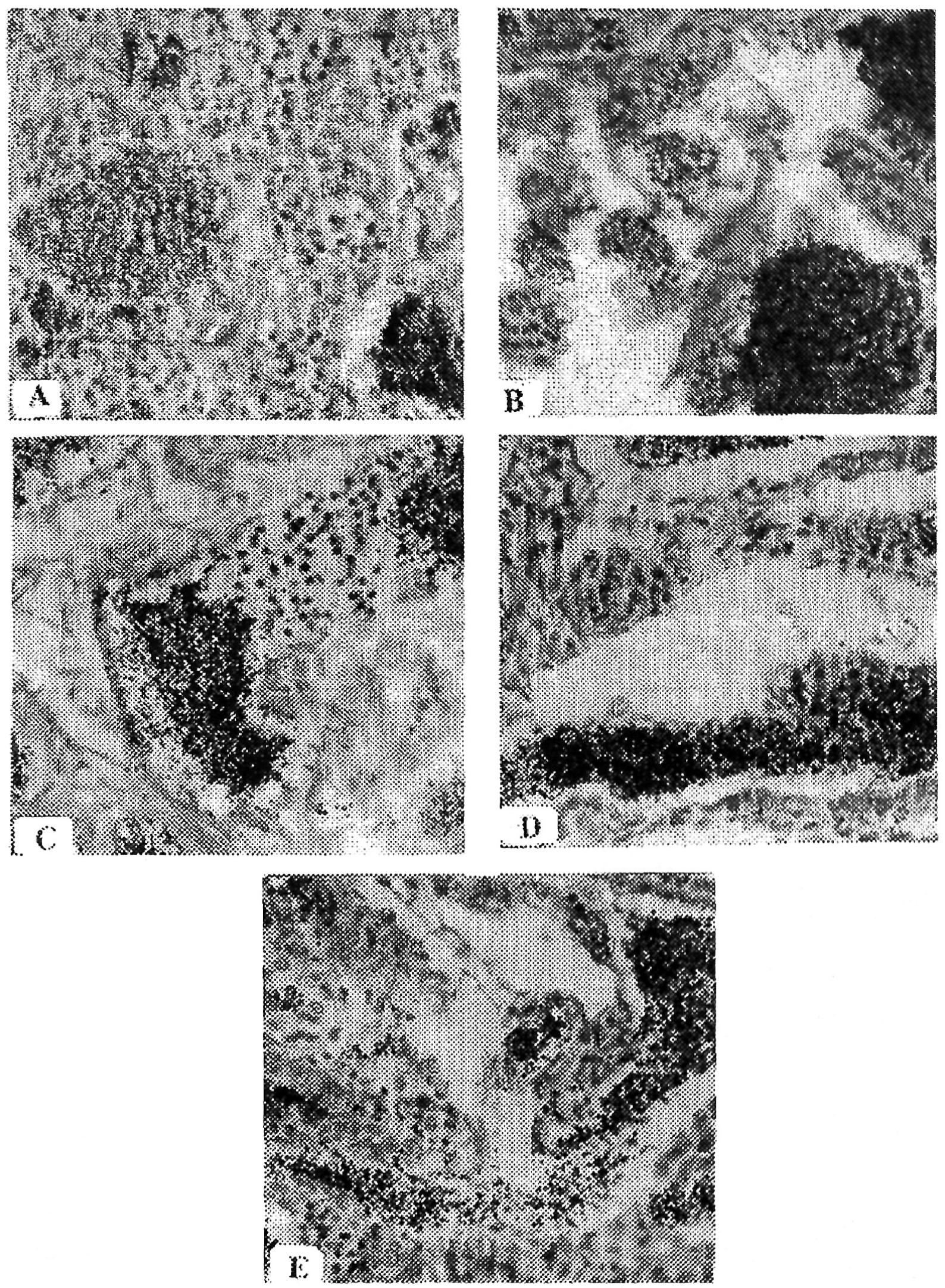

lig. (iy) 

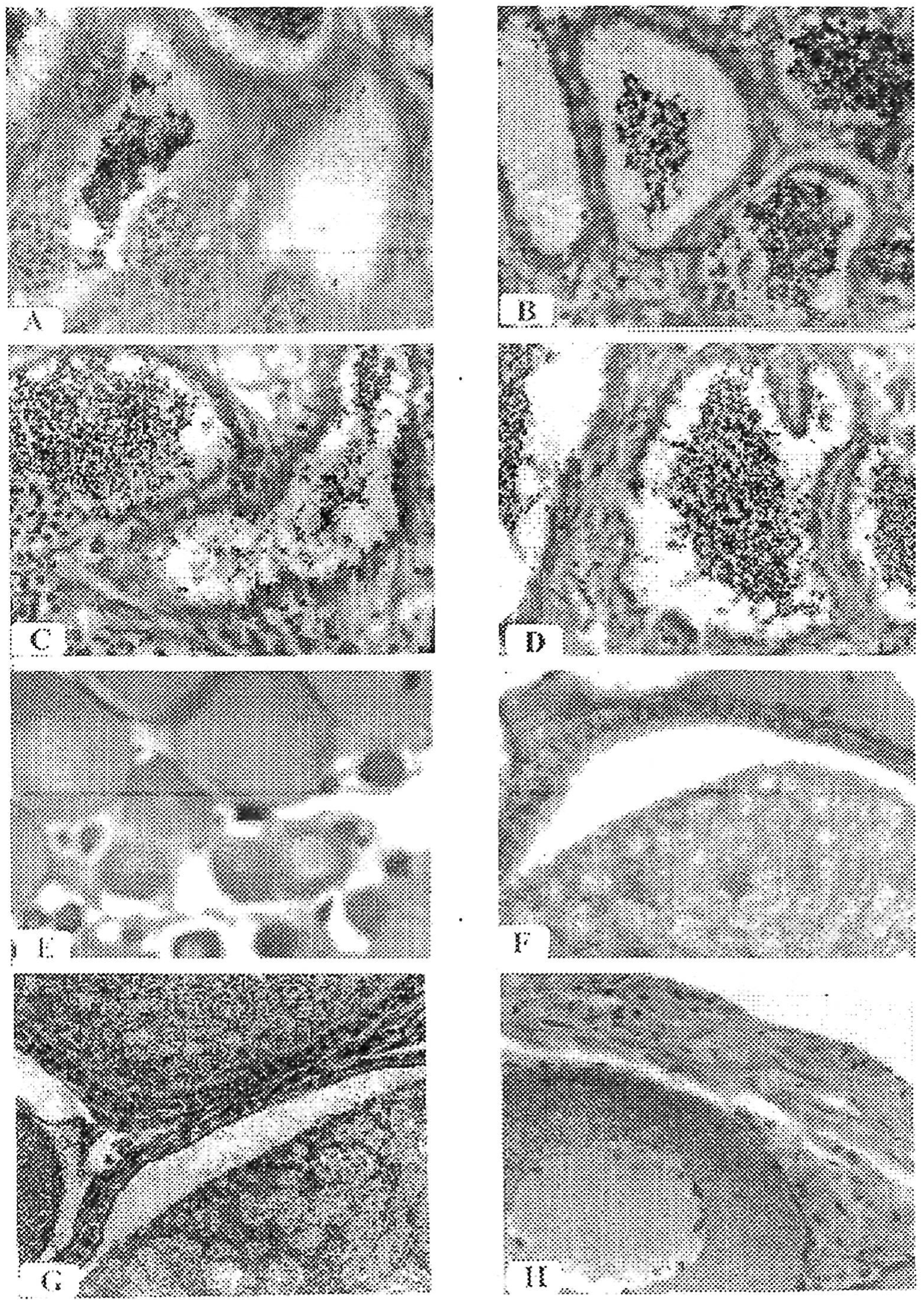

绕织. $($ IU) 

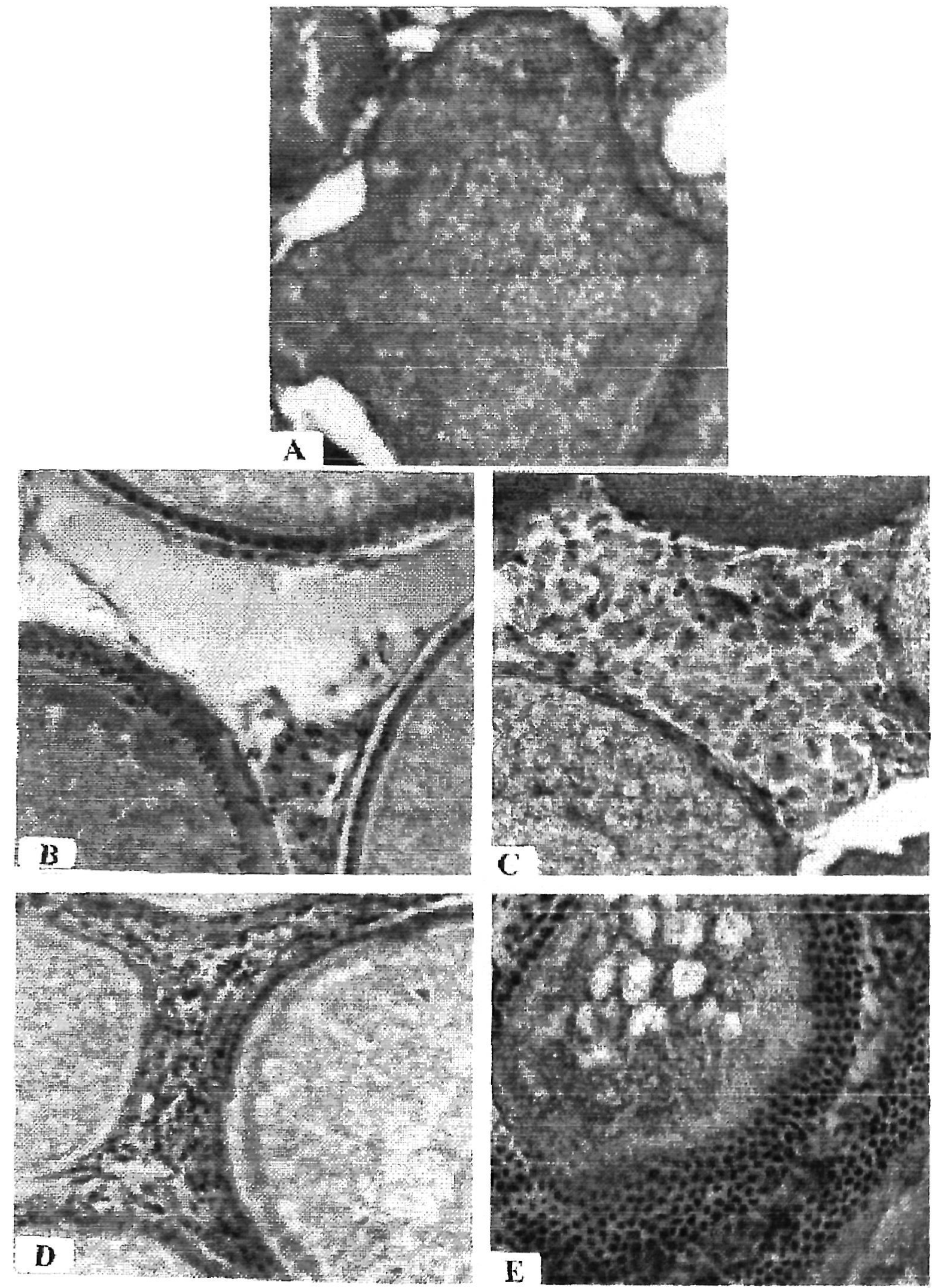

Fig. (11) 

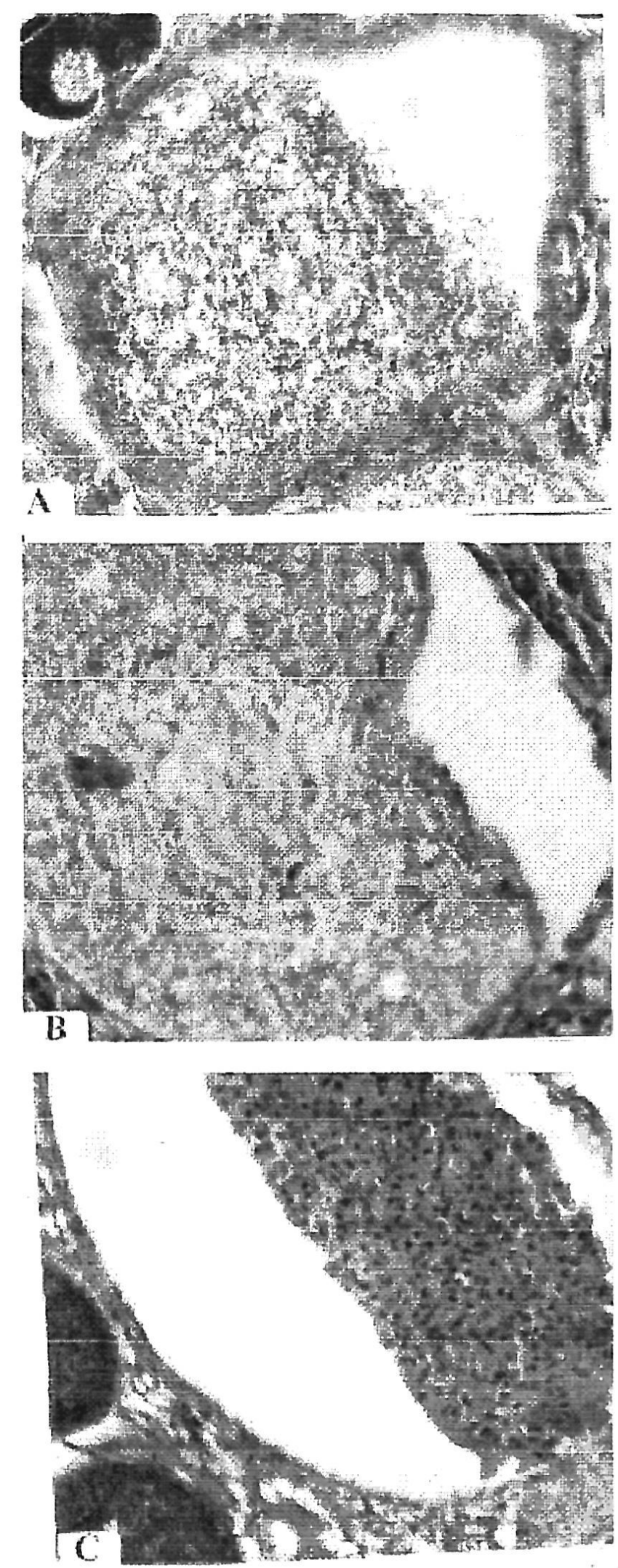

Fig. (12) 